\title{
Assessment and comparison of extreme sea levels and waves during the 2013/14 storm season in two UK coastal regions
}

\author{
M. P. Wadey ${ }^{1}$, J. M. Brown ${ }^{2}$, I. D. Haigh ${ }^{1,3}$, T. Dolphin ${ }^{4}$, and P. Wisse ${ }^{5}$ \\ ${ }^{1}$ Ocean and Earth Sciences, University of Southampton, National Oceanography Centre, Southampton, Hampshire, UK \\ ${ }^{2}$ National Oceanography Centre, Liverpool, Merseyside, UK \\ ${ }^{3}$ School of Civil, Environmental and Mining Engineering and the UWA Oceans Institute, The University of Western \\ Australia, Perth, Australia \\ ${ }^{4}$ The Centre for Environment, Fisheries \& Aquaculture Science (Cefas), Lowestoft, Suffolk, UK \\ ${ }^{5}$ Sefton Council, Bootle, Merseyside, UK \\ Correspondence to: M. P. Wadey (m.p.wadey@soton.ac.uk)
}

Received: 23 February 2015 - Published in Nat. Hazards Earth Syst. Sci. Discuss.: 16 April 2015

Revised: 3 September 2015 - Accepted: 20 September 2015 - Published: 8 October 2015

\begin{abstract}
The extreme sea levels and waves experienced around the UK's coast during the 2013/14 winter caused extensive coastal flooding and damage. Coastal managers seek to place such extremes in relation to the anticipated standards of flood protection, and the long-term recovery of the natural system. In this context, return periods are often used as a form of guidance. This paper provides these levels for the winter storms, and discusses their application to the given data sets for two UK case study sites: Sefton, northwest England, and Suffolk, east England. Tide gauge records and wave buoy data were used to compare the 2013/14 storms with return periods from a national data set, and also joint probabilities of sea level and wave heights were generated, incorporating the recent events. The 2013/14 high waters and waves were extreme due to the number of events, as well as the extremity of the 5 December 2013 "Xaver" storm, which had a high return period at both case study sites. The nationalscale impact of this event was due to its coincidence with spring high tide at multiple locations. Given that this event is such an outlier in the joint probability analyses of these observed data sets, and that the season saw several events in close succession, coastal defences appear to have provided a good level of protection. This type of assessment could in the future be recorded alongside defence performance and upgrade. Ideally other variables (e.g. river levels at estuarine locations) would also be included, and with appropriate offsetting for local trends (e.g. mean sea-level rise) so that the storm-driven component of coastal flood events can be de-
\end{abstract}

termined. This could allow long-term comparison of storm severity, and an assessment of how sea-level rise influences return levels over time, which is important for consideration of coastal resilience in strategic management plans.

\section{Introduction}

Storm surges and flooding are a threat to low-lying coastal zones, with risks increasing due to sea-level rise (Haigh et al., 2010; Menéndez and Woodworth, 2010; Wahl et al., 2011) and floodplain development (Hanson et al., 2011; Stevens et al., 2014, 2015). Northwest Europe, in which the case studies described in this paper are located, has historically suffered terrible losses from coastal flooding (Lamb, 1991; Gönnert et al., 2001). The worst event in living memory was the 31 January-1 February 1953 North Sea floods, which killed $>2100$ people, mostly in the Netherlands and along the UK east coast (Steers, 1953; Gerritsen, 2005; McRobie et al., 2005; Baxter, 2005). Recent and deadly reminders of the threat of coastal flooding include: Hurricane Katrina, 2005 (floods on the US Gulf Coast, > 900 people killed by flooding); Storm Xynthia, 2010 (French Atlantic coast, > 50 flooding fatalities); Hurricane Sandy, 2012 (US east coast 41 flooding fatalities); and Super Typhoon Haiyan, 2013 (Philippines).

More recently the 2013/14 winter in the UK and Ireland (BBC, 2014a) was the stormiest on record in 143 years 
(Matthews et al., 2014), and combined with large tides, caused an unusually clustered sequence of extreme coastal sea-level events (Wadey et al., 2014). The magnitude of these high waters and lack of time for recovery between events caused coastal erosion, damage to defences and flooding. This unusual "season" began with the St. Jude's Day Storm (27 October 2013), followed by extreme sea levels in early November. The most extreme and widespread coastal event of the season was the "Xaver Storm" and surge (5-6 December 2013), which flooded $>2800$ properties around the UK, including $>800$ in the east-coast town of Boston (Lincolnshire). Extreme sea levels, waves, erosion and floods continued to impact the west and south coast throughout early January 2014. On 5-6 February 2014 waves destroyed a section of the sea wall and railway line at Dawlish (Devon), followed by more storms during 10-15 February. The 14 February storm generated some of the largest sea levels on record on the central south coast (Wadey et al., 2015), with numerous flood incidences and calls to emergency services. The season continued to the 3 March 2014 with high tides and floods in the Channel Islands (BBC, 2014b).

The aim of this paper is to inform coastal managers of the extremity of the sea levels and waves during this unusual season, at two contrasting case study sites. It was widely perceived that despite the stress to which the coast was subjected during 2013/14, defences greatly reduced the consequences of these storms. This type of assessment initiates insight and discussion as to whether defences performed to their anticipated standards of protection, and also informs future defence design. This assessment was primarily undertaken via the commonly applied concept of joint probability analysis to generate return periods of high waters, waves and these combined, and comparison of 2013/14 with previous seasons. The objectives are as follows:

1. to identify the most extreme sea level and wave events of 2013/14 relative to long-term records;

2. to identify temporal clustering of these events in the span of the available observed data;

3. to compare and contrast the case studies to identify different return period characteristics and consequences;

4. to discuss implications for defence performance and coastal management.

The selected case study sites are Sefton (a district in northwest England), and Suffolk (a county on the east coast). These sites have several attributes that make them appropriate as case studies. At both sites there is active coastal monitoring and management; hence this research provides storm event thresholds to compare with past and future observations to inform shoreline management planning. These two case studies each have different coastal orientations and contrasting fetch limitations, experience some of the largest surges (reaching $>2 \mathrm{~m}$ ) within the UK (Lennon,

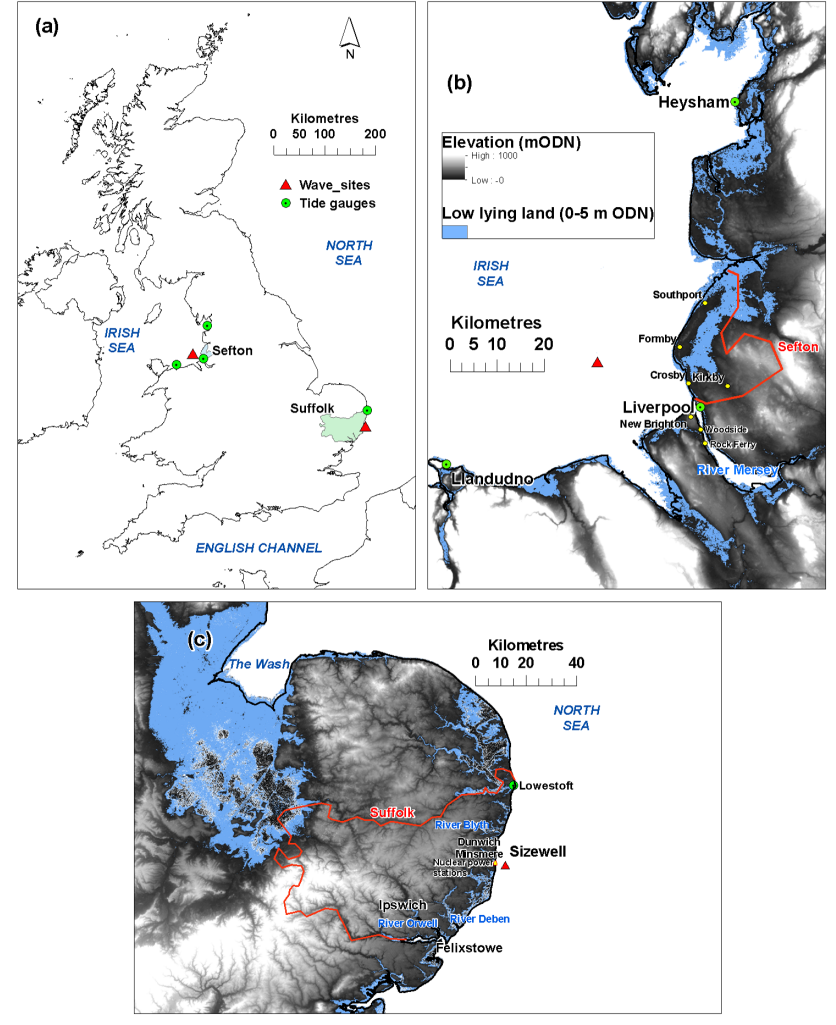

Figure 1. (a) Location of the case studies and data recorders, with a close-up of the floodplains in (b) Sefton and (c) Suffolk.

1963; Heaps, 1983) and host a variety of natural and manmade defences (Dolphin et al., 2007; Dissanayake et al., 2014).

The structure of this paper is as follows: Sect. 2 provides a background (to the case study areas and 2013/14 storms); Sect. 3 describes the data and methods; Sect. 4 provides the results for each objective; Sect. 5 discusses the results, comparing the two contrasting study sites and the applications for managers; and Sect. 6 presents the conclusions.

\section{Background}

The two case studies are summarised here, and their locations shown in Fig. 1. The Sefton case study site is in Liverpool Bay, a shallow and semi-enclosed area within the eastern Irish Sea. This west-facing coast extends for $36 \mathrm{~km}$ between the Mersey and the Ribble estuaries. In the context of shoreline management in England and Wales, Sefton lies where management cells (or process cells) (Motyka and Brampton, 1993; Cooper and Pontee, 2006) 11a and 11b meet. This coastline has a diverse range of environments, including estuaries, tidal flats, salt marshes, rapidly eroding dunes, defended shorelines, recreational beaches, urban areas and unspoilt and protected environments of high touristic value (Esteves et al., 2012). The coast is extensively 
monitored and managed, and the area is an internationally important nature conservation site which supports a declining population of red squirrels and natterjack toads (Plater and Grenville, 2010). Sefton typically experiences extreme waves and surges under southwest to north-westerly wind conditions (Pye and Blott, 2008). Extreme significant wave heights $\left(H_{\mathrm{S}}\right)$ during storms can exceed $5 \mathrm{~m}$, storm surges can exceed $2 \mathrm{~m}$ and the mean spring tidal range is $8.3 \mathrm{~m}$ (at Princes Pier, Liverpool). The storms that characteristically cause most impact on this coast are when a depression tracks across the Irish Sea from west to northwest, creating veering winds south-westerly to westerly over the longest fetches for surge and wave generation (Brown et al., 2010). The dominantly recreational beach at Formby (Sefton) includes a rapidly eroding dune system, with a predicted annual erosion rate of $4 \mathrm{~m} \mathrm{yr}^{-1}$ over the next century - during the 2013/14 storms alone, over $13 \mathrm{~m}$ was lost (NT, 2014; Smith, 2014). The coastal dunes here are amongst the largest in the UK, extending $16 \mathrm{~km}$ alongshore, $4 \mathrm{~km}$ inland and up to $30 \mathrm{~m}$ high (hence acting as a flood defence) and covering $21 \mathrm{~km}^{2}$ (Esteves et al., 2012). The 5 December 2013 and 3 January 2014 events caused the worst damage here during 2013/14 (Smith, 2014). The 5 December event caused floods within the Mersey Estuary: overall 19 businesses were flooded, as were four domestic properties (Wirral Council, 2014), at the Dell, Rock Ferry, and also at Woodside. Further downstream the promenade between Seacombe and New Brighton was overtopped, which damaged the promenade surface railings and wave return units particularly towards New Brighton. At New Brighton, flooding caused major disruption. Recovery since the recent 2013/14 storms has included reinstating beach access routes and new dune fences.

The Suffolk case study site (management cell 3c) borders the southern North Sea along approx. $78 \mathrm{~km}$ of shoreline (excluding tidal rivers). The county's landscape is dominated by agriculture, whilst urban areas lie at each end: Lowestoft to the north, Felixstowe to the south. Felixstowe has one of the largest container ports in Europe. The Sizewell nuclear power stations - one decommissioned, another active and a third planned (Sizewell C, EDF Energy, 2012) - lie behind the gravel barrier coast between Dunwich and Minsmere (EADT, 2013) which is an area of complex morphological evolution and nature conservation (Pye and Blott, 2006, 2009). The Suffolk coast faces southeast, and is situated in the open North Sea basin. Extreme wave and surge conditions are characteristically associated with winds from the north to northeast (Pye and Blott, 2006). The north coast is most exposed, with potential for extreme $H_{\mathrm{S}}>4 \mathrm{~m}$. Storm surges can exceed $2 \mathrm{~m}$ and the mean spring tidal range is $1.94 \mathrm{~m}$ (the tidal range in Suffolk increases from north to south). Dominant offshore wave directions tend to be from the north-northeast and south-southwest, and net wave energy at the shoreline tends to be from the east (Royal Haskoning, 2010). The coast around Dunwich and Sizewell has experienced major changes during the past two millennia, with significant loss of land caused by marine erosion (Pye and Blott, 2006). On this shoreline, local inshore wave heights, period and approach angle are strongly controlled by the morphology of the coastline, and by the offshore bathymetry. The importance of the offshore Sizewell-Dunwich bank to the reduction of wave energy that reaches the coast, varies alongshore due to different shoaling (or even breaking) over the variable elevation and width of the bank (Tucker et al., 1983). The worst floods in living memory were during 31 January-1 February 1953, when 45 people were killed in Suffolk. The 1953 storm characterised the worst conditions to impact this area of coast (cf. Flather, 1984): a deep Atlantic depression which passed to the north of Scotland and moved southeast down the North Sea. The northerly gales on the western side of this depression forced seawater south at the time of high tide, causing a surge, whilst the wind field veered from northerly to north-easterly over the longest fetches, generating extreme waves at the coast. The most severe 2013/14 event in Suffolk was 5 December 2013, which flooded 231 properties in the county. Ipswich and Felixstowe escaped substantial damage, although a number of locations such as Waldringfield (on the tidal Deben) suffered extensive flooding. At Lowestoft 143 commercial and 90 residential properties were affected (compared with 400 properties in 1953). Almost 170 properties were flooded in the Waveney district, with some breaches as large as $30 \mathrm{~m}$ wide (SDC, 2014; SFCN, 2014). A total of 22 breaches were reported; in one case, the hamlet of Woodbridge was "cut off" (BBC, 2013a). Failure of the sea defences at Blythburgh caused the closure of the A12 road, the vital link between Lowestoft and Ipswich. Rail services between Lowestoft and Norwich, and Lowestoft and Ipswich, were disrupted as a consequence of flooding at Lowestoft Central and damage to the signalling network. The Lowestoft to Ipswich line was closed for 11 days after the surge (SDC, 2014; SFCN, 2014).

\section{Data and methods}

Both Sefton and Suffolk have wave-recording devices located nearby (Directional Waverider ${ }^{\circledR}$ MkIII). These are part of the WaveNet system of nearshore wave buoys deployed since 2002 (Fig. 2), and maintained for the Environment Agency (EA) and Department of Environment Food and Rural Affairs (DEFRA) by the Centre for Environment, Fisheries and Aquaculture Science (CEFAS). One of these wave buoys is offshore from Sefton, near the Liverpool Bar Light in $22 \mathrm{~m}$ water depth. This has provided over 12 complete years of directional wave observations. The Suffolk data used here are from the Sizewell wave buoy in $18 \mathrm{~m}$ water depth and has been operational for approx. 6 years. The data time series is provided at $30 \mathrm{~min}$ temporal resolution. Observed sea-level time series at both sites was used from the UK's "Class A" network of tide gauges, managed by the National Tide and Sea Level Facility (NTSLF), owned and funded 


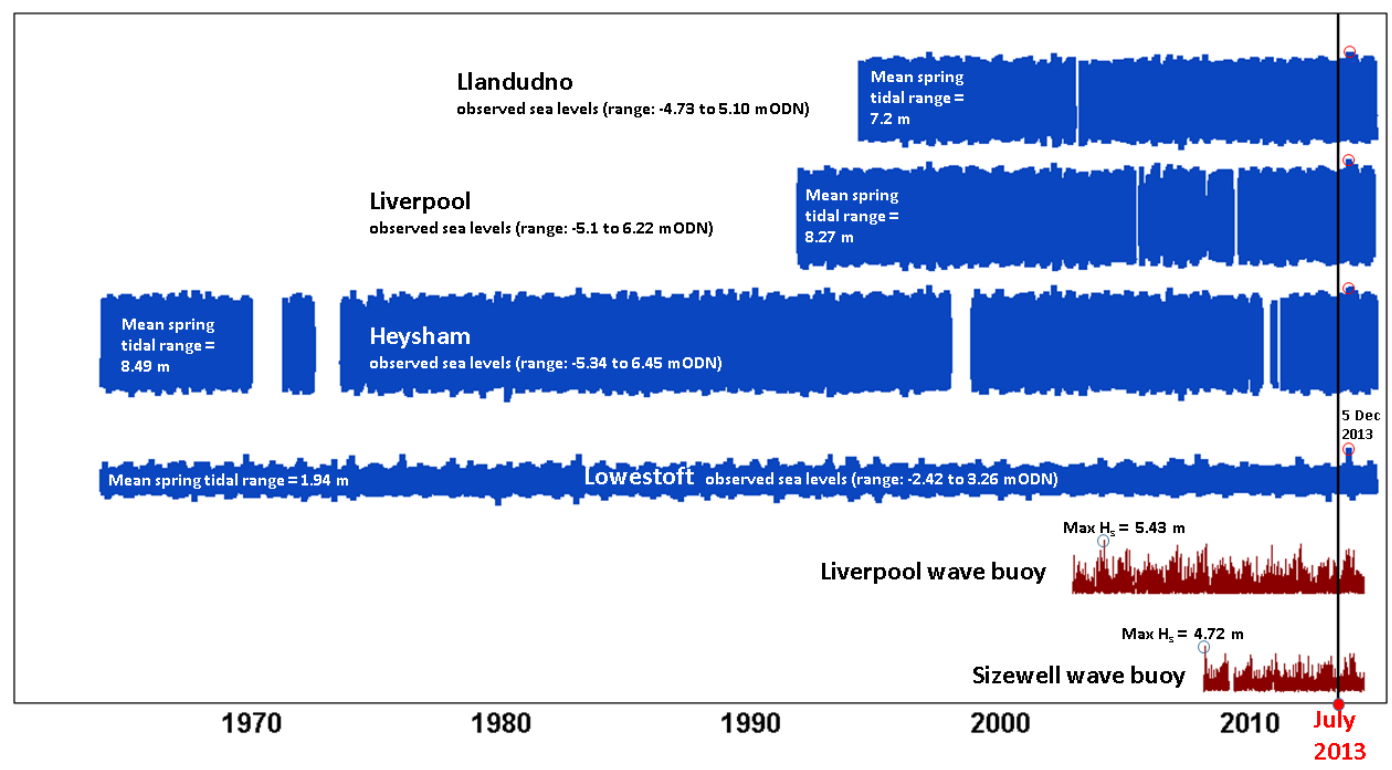

Figure 2. Observed tide gauge and wave data availability that was used to assess the 2013/14 winter (BODC water level record and CEFAS wave records) - diagram is to scale.

by the EA. The data are quality-controlled and archived by the British Oceanographic Data Centre (BODC). Fifteen minutely data values are available for January 1993 onwards and hourly values prior to 1993 (Fig. 2). The sampling frequency of these time series were not changed (i.e. interpolated) for this analysis. These sampling rates filter out highfrequency seiches, swell and wind waves. UK tide gauges are regularly levelled and checked. The BODC's archived data are accompanied by flags which identify problematic data and we also undertook secondary checks. The closest tide gauge to Sefton is Liverpool (sea levels from surrounding gauges at Heysham and Llandudno are also briefly discussed), and the wave buoy is $16 \mathrm{~km}$ offshore. For the Suffolk case study, data from the Lowestoft tide gauge was used, and the Sizewell Waverider buoy which is $4 \mathrm{~km}$ offshore.

The observed sea-level record was separated into its main component parts (Pugh, 2004): mean sea level (MSL); astronomical tide (AT); and non-tidal residual (NTR) (see also Wadey et al., 2014). We refer to the "skew surge" which is the difference between the elevation of observed high water $(\mathrm{HW})$ and the corresponding value of the predicted AT peak - a more relevant measure of flood risk than residuals elsewhere in the tidal cycle (Horsburgh and Wilson, 2007). To assess return periods of each HW, we used a UKwide assessment of the joint probability of tide and skew surge from the Environment Agency's national extreme value statistics for sea level (McMillan et al., 2011a; Batstone et al., 2013). These return periods are referenced to a 2008 MSL baseline; therefore the HW level was offset to remove the influence of mean sea-level rise (SLR) on the extreme water levels relative to the year 2008 (Wadey et al., 2014) (Fig. 3). Over these multi-decadal observations, this provides a better isolation of the storm-tide-driven component responsible for causing the extreme high waters (HWs). For this we use linear SLR trends. These were calculated at Heysham $+2.00 \mathrm{~mm} \mathrm{yr}^{-1}$, and at Lowestoft $+2.99 \mathrm{~mm} \mathrm{yr}^{-1}$. The records at Llandudno and Liverpool are too short and may provide misleading rates. Mean SLR at Liverpool was assessed by Woodworth et al. (2009), which suggested a trend 1901-2004 of $+1.82 \pm 0.13 \mathrm{~mm}$ per year; whilst for the UK's highest quality long-term record (Newlyn, since 1915) a rate of approx. $+1.8 \mathrm{~mm} \mathrm{yr}^{-1}$ has been calculated (Araújo and Pugh, 2008; Wadey et al., 2014), which is similar to the average global rate (and this was applied to the return period offset for Llandudno and Liverpool). It should also be noted that since the 1990s, satellite altimetry indicates higher recent global averaged rates in the order of $+3 \mathrm{~mm} \mathrm{yr}^{-1}$ (Church and White, 2006). In the UK, there are also regional variations in sea-level change, mainly due to uplift/subsidence of land with different geological and glacial history (Shennan and Horton, 2002; Bradley et al., 2009).

Wave events were defined as the peak $H_{\mathrm{S}}$ of a storm event (where each event was separated by $>24 \mathrm{~h}$ and was above the level of the 1 in $1 H_{\mathrm{S}}$ return period level). A national swell wave return period data set exists (McMillan et al., 2011b) but at each case study site, the locally generated wind waves are important for causing higher total sea states. Therefore a Weibull distribution was applied for an extreme value analysis of $H_{\mathrm{S}}$. This generated return periods from the observed wave event time series, and also a 30 year model hindcast provided by CEFAS (Leonard-Williams and Saulter, 2013) at the Waverider ${ }^{\circledR}$ locations. As shown in Table 1, it is clear that the longer 30 year hindcast data have higher $H_{\mathrm{S}}$ levels for 

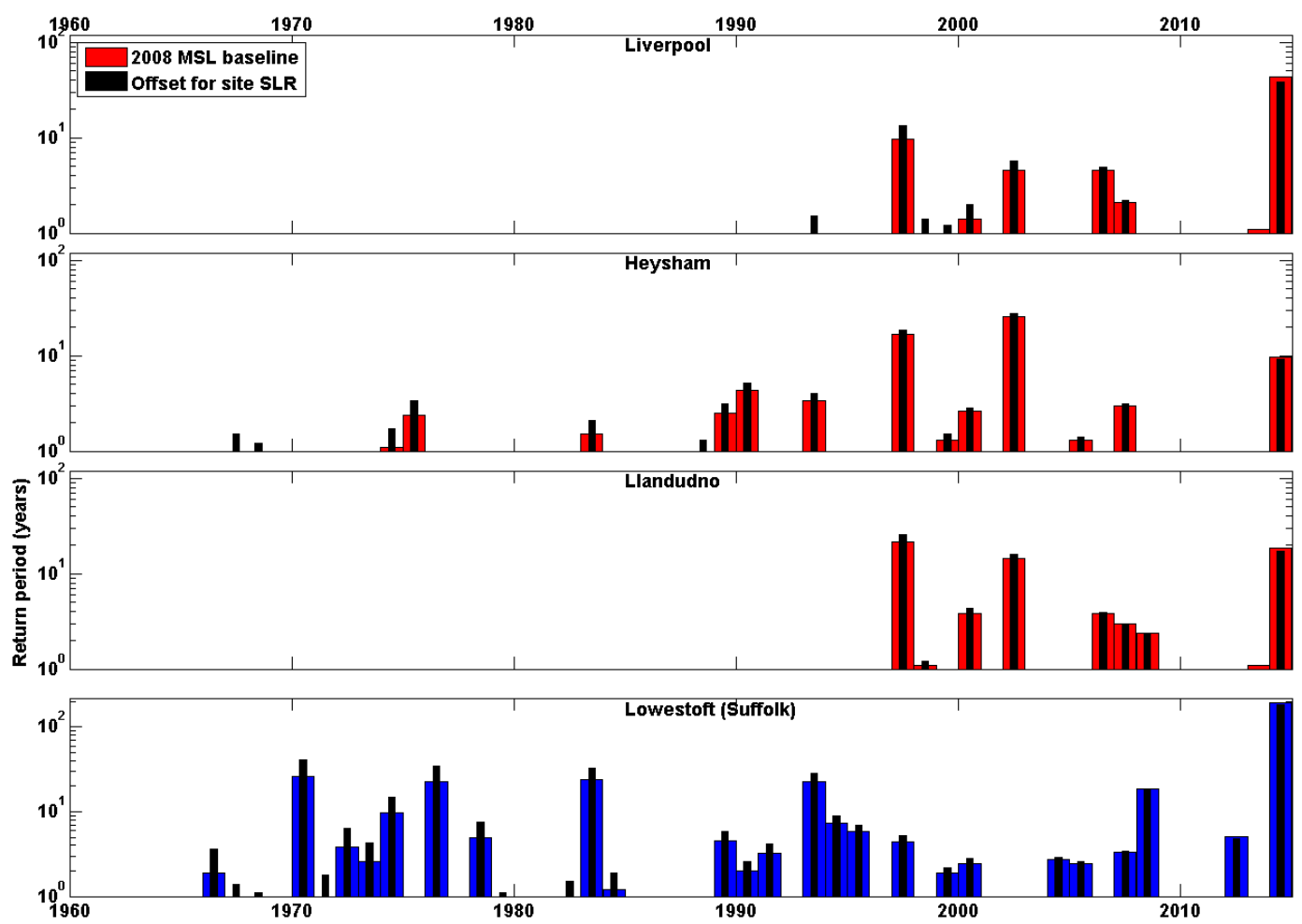

Figure 3. High water probabilities for the largest event in each annual winter "season" at the sites near Sefton, and Lowestoft in Suffolk. Liverpool is primarily relevant to Sefton, but Llandudno and Heysham are nearby and the latter has a longer data record. Note that the EA return sea-level periods are relative to a baseline MSL for the year 2008, so in black we have offset for sea-level rise (cf. Haigh et al., 2010; Wadey et al., 2014).

each return period. Since longer data sets are preferable for extreme event analysis, the levels generated from the 30 year hindcast were used to attribute $H_{\mathrm{S}}$ return levels to the observed events. Due to fetch limitations in the eastern Irish Sea, higher return periods are associated with a small increase in the wave height. Figure 4 provides a view of wave events and the corresponding wave periods - it is acknowledged that ideally a fuller assessment of wave events would incorporate period, direction and duration.

For the joint probability HW and $H_{\mathrm{S}}$ assessment (Fig. 5), a data set was assembled of every HW and corresponding $H_{\mathrm{S}}$ at the time of each HW. For Sefton this was data from the wave and tide recorders at Liverpool, and for Suffolk the wave buoy at Sizewell and tide gauge at Lowestoft. The joint probability of $\mathrm{HW}$ elevations and $H_{\mathrm{S}}$ occurring together from this data set was calculated using the JOINSEA software (Hawkes and Gouldby, 1998; Hawkes et al., 2002). This approach has been extensively applied and validated (Hawkes and Svensson, 2003), and is based upon principles described in Coles and Tawn (1990). Generalised Pareto distributions are fitted to the top few percent of the marginal variables (i.e. HW and coincident $H_{\mathrm{S}}$ ), and dependence models (a single bivariate normal (BVN) distribution and a mixture of two BVNs) are applied to the observed data to generate a large sample of random pairs of wave heights and sea levels, which are based on the fitted distributions, and with the same statistical characteristics as the input data. This allows 1000s of years of sea conditions to be simulated with fitted distributions, extremes and dependences. Extreme values are calculated below the upper tails of statistical distributions defined in the software. However in our case studies, due to the requirement for a seamless data set of combined $H_{\mathrm{S}}$ and HWs, the data sets are shortened by the limited length of the wave observations. Therefore the resultant return periods should be treated with caution. At Liverpool this was a data set of 6836 HWs (with corresponding $H_{\mathrm{S}}$ ) and at Suffolk this was 4030 records. Due to the short timescale of observations, a sealevel rise offset to modify the HW elevation relative to the first year of observations has not been included (tests showed this to have a nominal effect on return periods across these short data sets).

To assess the temporal nature of the sea level and wave events during the 2013/14 storm season, the frequency of events above the 1 in 1 year return levels were analysed. The objective was to determine if 2013/14 was indeed unusual in terms of the "clustering" of distinct $\mathrm{HW}$ and $H_{\mathrm{S}}$ extremes compared with other seasons. In the UK, extreme coastal events (due to storms and high tides) tend to occur between October and April (Wadey et al., 2014); hence to compare extreme event clusters, we defined "seasons" for year-on-year 
Table 1. Summary of return period data: the water level return heights are those from McMillan et al. (2011a), and the significant wave heights $\left(H_{\mathrm{S}}\right)$ were calculated via a Weibull distribution.

\begin{tabular}{|c|c|c|c|c|c|c|}
\hline \multirow{2}{*}{$\begin{array}{l}\text { Return period } \\
\text { (years) }\end{array}$} & \multicolumn{3}{|c|}{ Sefton (Liverpool tide gauge and Waverider) - return heights } & \multicolumn{3}{|c|}{ Suffolk (Lowestoft tide gauge and Waverider) - return heights } \\
\hline & $\begin{array}{l}\text { Water level } \\
(\mathrm{m} \text { ODN) }\end{array}$ & $\begin{array}{c}H_{\mathrm{S}}(\mathrm{m}) \\
\text { observed data }\end{array}$ & $\begin{array}{c}H_{\mathrm{S}}(\mathrm{m}) \\
30 \text { year hindcast }\end{array}$ & $\begin{array}{l}\text { Water level } \\
(\mathrm{m} \text { ODN) }\end{array}$ & $\begin{array}{c}H_{\mathrm{S}}(\mathrm{m}) \\
\text { observed data }\end{array}$ & $\begin{array}{c}H_{\mathrm{S}}(\mathrm{m}) \\
30 \text { year hindcast }\end{array}$ \\
\hline 1 & 5.51 & 3.36 & 4.21 & 2.00 & 3.13 & 3.68 \\
\hline 2 & 5.62 & 3.57 & 4.37 & 2.14 & 3.28 & 3.80 \\
\hline 5 & 5.77 & 3.79 & 4.55 & 2.33 & 3.44 & 3.94 \\
\hline 10 & 5.90 & 3.93 & 4.68 & 2.48 & 3.54 & 4.03 \\
\hline 50 & 6.25 & 4.19 & 4.93 & 2.88 & 3.73 & 4.21 \\
\hline 100 & 6.42 & 4.29 & 5.03 & 3.07 & 3.80 & 4.28 \\
\hline 1000 & 6.87 & 4.56 & 5.31 & 3.78 & 4.00 & 4.49 \\
\hline
\end{tabular}
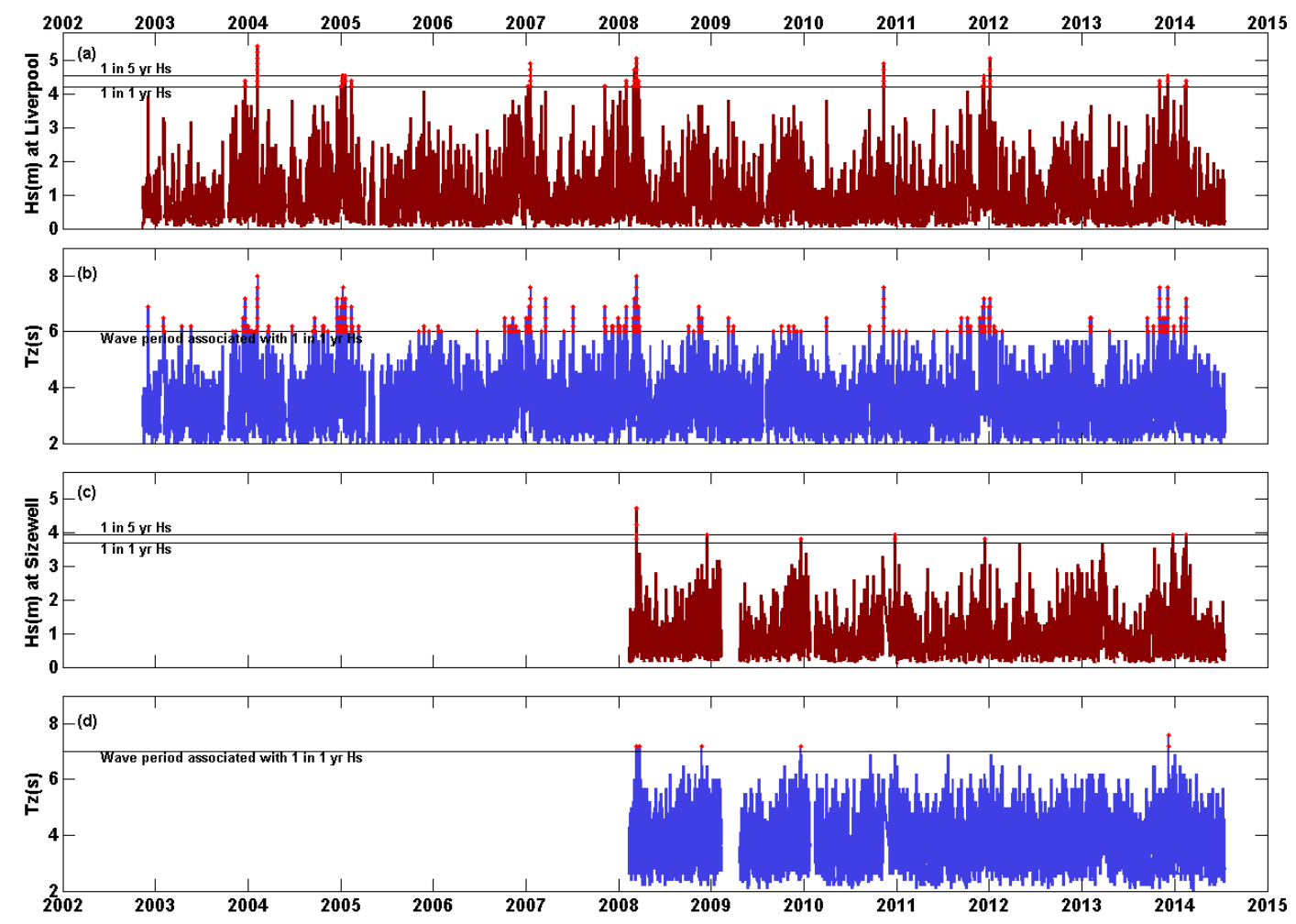

Figure 4. Wave time series and return period thresholds, (a) significant wave height $\left(H_{\mathrm{S}}\right)$ at Liverpool, (b) zero crossing over wave period $\left(T_{Z}\right)$ at Liverpool; the line is the approx. wave period most commonly associated with a larger than 1 in 1 year $H_{\mathrm{S}}$; (c) $H_{\mathrm{S}}$ at Sizewell (Suffolk) and (d) $T_{Z}$ at Sizewell.

comparison (grouped by events that fall within the time period of 1 July of one year to 30 June of the following year).

\section{Results}

\subsection{Sea level and wave height return periods}

Objective 1, to summarise the extreme $\mathrm{HW}$ and $H_{\mathrm{S}}$ events of 2013/14, is addressed firstly for Sefton then Suffolk. Each event during the annual season was associated with a return level for $\mathrm{HW}, H_{\mathrm{S}}$ and the joint (HW and coincident $H_{\mathrm{S}}$ ) level
(JL). Extreme events during the 2013/14 season were identified at each location if HW exceeded the 1 in 1 year threshold defined by McMillan et al. (2011a), or if $H_{\mathrm{S}}$ exceeded the 1 in 1 year threshold (Fig. 4) defined by the 30 year wave hindcast (Table 1) or if the JL exceeds the joint 1 in 1 year threshold (Fig. 5).

At Sefton, 14 instances of extreme conditions were identified (Table 2). Out of these, six can be considered extreme due to HW (sea levels), three were extreme due to the $H_{\mathrm{S}}$ (wave heights) and 13 were extreme due to the JL conditions. The sea-level return periods of McMillan et al. (2011a) 
Table 2. Time instances of extreme conditions $\geq 1$ in 1 year return period (RP) during the winter of 2013/14 at Sefton. Event groups $1-3$, 5-8, 9-12 and 13 include secondary storms that quickly followed the first - the earlier storm usually was the larger event. The bracketed values represent the values when HW is offset for MSL, relevant only to the (longer) sea-level records.

\begin{tabular}{|c|c|c|c|c|c|c|c|c|c|c|}
\hline \multirow[t]{2}{*}{$\begin{array}{l}\text { Instances of extreme high water }(\mathrm{HW}) \\
\text { and/or sign wave height }\left(H_{\mathrm{S}}\right)\end{array}$} & \multirow[t]{2}{*}{$\begin{array}{l}\text { Context in which the } \\
\text { instance is extreme }\end{array}$} & \multirow[t]{2}{*}{ Date, time } & \multicolumn{4}{|c|}{$\begin{array}{c}\text { Sea level } \\
\text { Return period value refers to year 2008 MSL } \\
\text { (Value offset for SLR trend shown in brackets) }\end{array}$} & \multicolumn{3}{|c|}{ Waves } & \multirow[t]{2}{*}{$\begin{array}{c}\text { Joint level (HW and } \\
\left.H_{\mathrm{S}}\right) \mathrm{RP}\end{array}$} \\
\hline & & & $\begin{array}{c}\mathrm{HW} \\
(\mathrm{mODN})\end{array}$ & $\begin{array}{c}\text { Tide } \\
(\mathrm{mODN})\end{array}$ & $\begin{array}{l}\text { Skew surge } \\
(\mathrm{m})\end{array}$ & $\mathrm{RP}$ & $\begin{array}{l}H_{\mathrm{S}} \\
(\mathrm{m})\end{array}$ & $\begin{array}{l}T_{Z} \\
(\mathrm{~s})\end{array}$ & $\mathrm{RP}$ & \\
\hline \multirow[t]{3}{*}{$1-3$} & $\mathrm{JL}$ & 2 Nov $2013,22: 00$ & 5.20 & 4.37 & 0.83 & $<1$ & 3.80 & 6.20 & $<1$ & 35 \\
\hline & $H_{\mathrm{S}}$ & $\begin{array}{l}3 \text { Nov 2013, 23:45 } \\
\text { (wave peak: 00:30) }\end{array}$ & 4.80 & 4.62 & 0.19 & $<1$ & 4.39 & 7.60 & 2 & $<1$ \\
\hline & $\mathrm{JL}$ & 5 Nov $2013,11: 45$ & 5.30 & 4.82 & 0.48 & $<1$ & 1.81 & 4.10 & $<1$ & 2 \\
\hline 4 & $\mathrm{HW}, H_{\mathrm{S}}, \mathrm{JL}$ & $5 \operatorname{Dec} 2013,12: 30$ & 6.22 & 5.13 & 1.09 & $44(38)$ & 4.55 & 6.90 & 5 & $>200$ \\
\hline \multirow[t]{3}{*}{$5-8$} & HW, JL & 3 Jan $2014,12: 00$ & 5.86 & 5.49 & 0.37 & $8(7)$ & 2.23 & 5.00 & $<1$ & 75 \\
\hline & JL & 4 Jan $2014,00: 30$ & 5.26 & 5.13 & 0.13 & $<1$ & 2.51 & 5.00 & $<1$ & 4 \\
\hline & $\mathrm{JL}$ & 6 Jan $2014,14: 30$ & 5.36 & 4.90 & 0.46 & $<1$ & 1.97 & 4.60 & $<1$ & 4 \\
\hline \multirow[t]{4}{*}{$9-12$} & HW, JL & 1 Feb 2014, 11:45 & 5.66 & 5.52 & 0.14 & $3(2)$ & 2.14 & 4.50 & $<1$ & 15 \\
\hline & $\mathrm{JL}$ & 2 Feb $2014,00: 15$ & 5.36 & 5.18 & 0.18 & $<1$ & 1.97 & 4.60 & $<1$ & 4 \\
\hline & HW, JL & 2 Feb $2014,12: 45$ & 5.53 & 5.49 & 0.04 & $1(1)$ & 1.46 & 4.30 & $<1$ & 4 \\
\hline & HW, JL & 3 Feb $2014,13: 30$ & 5.57 & 5.26 & 0.31 & $1(1)$ & 1.39 & 3.90 & $<1$ & 4 \\
\hline \multirow[t]{2}{*}{13} & WH, JL & 12 Feb $2014,21: 45$ & 4.29 & 3.49 & 0.80 & $<1$ & 4.39 & 6.90 & 2 & 8 \\
\hline & $\mathrm{JL}$ & 15 Feb $2014,11: 30$ & 4.87 & 4.32 & 0.55 & $<1$ & 2.71 & 5.50 & $<1$ & 2 \\
\hline 14 & HW, JL & 2 Mar 2014, 11:30 & 5.60 & 5.40 & 0.20 & $2(1)$ & 0.52 & 2.90 & $<1$ & 2 \\
\hline
\end{tabular}

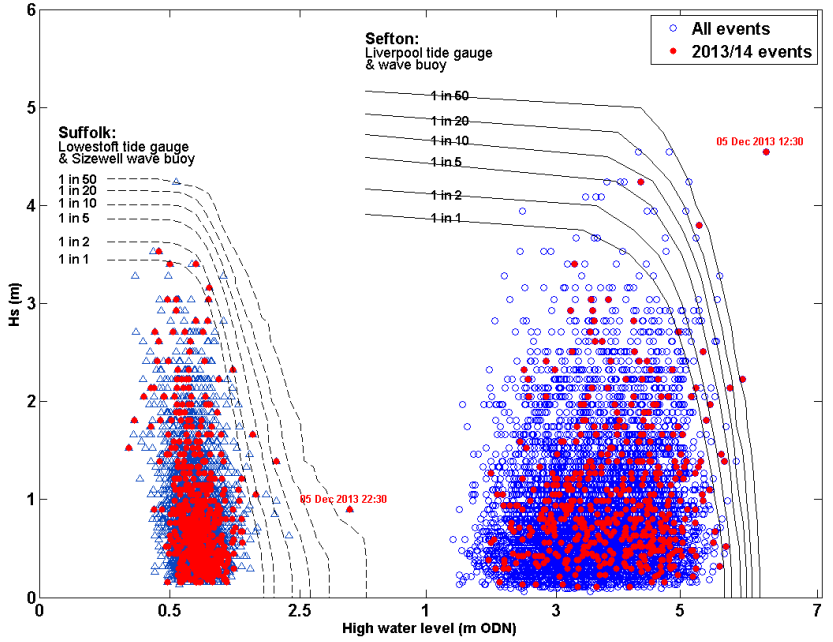

Figure 5. High water and significant wave height $\left(H_{S}\right)$ jointprobability curves and events at Sefton and Suffolk. Data length limits the accuracy of return period analyses, hence only up to $1: 50$ years is shown - in the text we note that the 5 December 2013 event at Liverpool may have exceeded the 1 in 200 year level.

approximated that the most extreme HW event at Liverpool tide gauge was a 1 in 44 year return period (12:30, 5 December 2013). This was the largest HW in this database (since 1992) and was $0.33 \mathrm{~m}$ higher than the previous largest, (10 February 1997). The offset in HW due to the local MSL trend causes a negligible reduction in the sea-level return period for events over this season. The largest wave event during 2013/14 was also on 5 December 2013, and was at the same time as the extreme HW (12:30), with $H_{\mathrm{S}} 4.55 \mathrm{~m}$ (and $T_{Z} 6.9 \mathrm{~s}$ ) rated as a 1 in 5 year return period. The next largest wave event of the season was on 3 November 2013 ( $\left.H_{\mathrm{S}} 4.30 \mathrm{~m}, T_{Z} 7.6 \mathrm{~s}\right)$. The largest $H_{\mathrm{S}}$ in the observational data set was $5.43 \mathrm{~m}$ measured on 8 February 2004. The coincidence of such large wave conditions with HW meant that the 5 December event was rare. The analysis of the combined 12 year $\mathrm{HW}$ and $H_{\mathrm{S}}$ record confirmed that this event was the largest JL in the 2013/14 season and in this data set. The veering $\mathrm{W}-\mathrm{NW}$ wind directions during the morning rising tide (Figs. 7 and 8) caused large wave and surge conditions for Liverpool, which when combined with large spring tides (also a year before the maxima in the nodal cycle) and large skew surge, resulted in an extreme HW. This coincidence of large waves at the time of HW increased the return period estimates from those associated with the isolated $H_{\mathrm{S}}$ or HW values, to an estimated JL of $>1$ in 200 years. There were other notable events, for example on 1-3 February 2014, and in other events, smaller wave conditions occurred but were prolonged over multiple tidal HWs, creating consecutive instances of extreme JL conditions.

The tide gauges either side of Liverpool (Heysham which is $55 \mathrm{~km}$ north of Sefton, and Llandudno $55 \mathrm{~km}$ southwest of Sefton) were also affected by these storm events. The 5 December 2013 event stands out at all of these sites, although the 3 January 2014 HW was the largest event of 2013/14 at Llandudno and Heysham. Using the SLR offset values, the 5 December 2013 was a 1 in 15 year HW at Llandudno and 1 in 4 year HW at Heysham, ranked as the fourth and third largest events in these records, respectively; whereas the 3 January $2014 \mathrm{HW}$ was a 1 in 17 and 1 in 9 year HW, respectively. Events on 10 February 1997 and 1 February 2002 were more extreme sea-level occurrences at Llandudno and 
Table 3. Time instances of extreme conditions which exceeded the 1 in 1 year return period (RP) of 2013/14 at Suffolk. The bracketed values in the RP column represent the values when HW is offset for mean sea level.

\begin{tabular}{|c|c|c|c|c|c|c|c|c|c|c|}
\hline \multirow{2}{*}{$\begin{array}{l}\text { Instances of extreme high } \\
\text { water and/or waves }\end{array}$} & \multirow{2}{*}{$\begin{array}{l}\text { Context in which the } \\
\text { instance is extreme }\end{array}$} & \multirow[t]{2}{*}{ Date, time } & \multicolumn{4}{|c|}{ Sea level } & \multicolumn{3}{|c|}{ Waves } & \multirow{2}{*}{$\begin{array}{c}\text { Joint level (HW and } \\
\left.H_{\mathrm{S}}\right) \mathrm{RP}\end{array}$} \\
\hline & & & $\begin{array}{c}\mathrm{HW} \\
(\mathrm{mODN})\end{array}$ & $\begin{array}{c}\text { Tide } \\
(\mathrm{mODN})\end{array}$ & $\begin{array}{l}\text { Skew surge } \\
(\mathrm{m})\end{array}$ & $\mathrm{RP}$ & $\begin{array}{l}H_{\mathrm{S}} \\
(\mathrm{m})\end{array}$ & $\begin{array}{l}T_{Z} \\
(\mathrm{~s})\end{array}$ & $\mathrm{RP}$ & \\
\hline \multirow[t]{3}{*}{$1-3$} & $\mathrm{JL}$ & 10 Oct $2013,12: 30$ & 1.78 & 1.13 & 0.65 & $<1$ & 1.66 & 4.00 & $<1$ & 4 \\
\hline & $\mathrm{JL}$ & 11 Oct $2013,01: 00$ & 1.47 & 1.10 & 0.37 & $<1$ & 2.32 & 4.80 & $<1$ & 2 \\
\hline & $\mathrm{JL}$ & 12 Oct $2013,01: 15$ & 1.11 & 1.04 & 0.07 & $<1$ & 3.16 & 5.70 & $<1$ & 2 \\
\hline \multirow[t]{2}{*}{$4-5$} & HW, JL & 5 Dec $2013,22: 30$ & 3.26 & 1.28 & 1.98 & $196(189)$ & 0.90 & 4.80 & $<1$ & 75 \\
\hline & HW, JL & 6 Dec $2013,11: 15$ & 2.13 & 1.09 & 1.04 & $2(2)$ & 1.39 & 5.20 & $<1$ & 15 \\
\hline 6 & $\mathrm{JL}$ & $19 \operatorname{Dec} 2013,22: 15$ & 1.82 & 1.07 & 0.75 & $<1$ & 1.05 & 4.8 & $<1$ & 4 \\
\hline 7 & $H_{\mathrm{S}}$ & $\begin{array}{l}24 \text { Dec 2013, 03:00 } \\
\text { (time of wave peak, HW: 00:45) }\end{array}$ & 0.33 & 0.88 & -0.55 & $<1$ & 3.95 & 6.50 & 5 & 2 \\
\hline 8 & $\mathrm{JL}$ & 1 Jan $2014,20: 45$ & 0.9 & 0.91 & -0.01 & $<1$ & 3.40 & 6.90 & $<1$ & 2 \\
\hline 9 & $H_{\mathrm{S}}$ & $\begin{array}{l}14 \text { Feb 2014, 22:30 } \\
\text { (wave peak, HW: 20:15) }\end{array}$ & 0.6 & 0.84 & -0.24 & $<1$ & 3.94 & 5.50 & 5 & $<1$ \\
\hline
\end{tabular}

Heysham than they were at Liverpool, and at Heysham were larger than any other HW of 2013/14.

At Suffolk (Table 3) there were nine instances of extreme conditions. Out of these, two were extreme due to the HW, two were extreme due to $H_{\mathrm{S}}$ and eight were extreme due to the JL. For the 10-12 October 2013 storm, and the HWs on 6 December and 19 December, it is seen that considering sea levels and waves together increases the return period value assigned to the event (compared with the HW and $H_{\mathrm{S}}$ return periods taken in isolation). The largest $\mathrm{HW}$ at Lowestoft was 1 in 196 years on 5 December 2013, 22:30, the largest event in the BODC database for Lowestoft, (a record dating back to 1964), $0.55 \mathrm{~m}$ higher than the previous largest HW (29 September 1969). However the HW of 31 January 1953 (Rossiter, 1954; not in the BODC database) was $0.18 \mathrm{~m}$ larger than 5 December 2013. The 5-6 December event caused the two highest JL values of 2013/14, and on consecutive high tides. On the later of these tides (11:30, 6 December) the wave conditions were larger and, and the return period is higher if considering the JL rather than the HW ( 1 in 2 year HW, 1 in 15 year JL). Less damage was experienced on the second tide (6 December) although waves did overtop onto the promenade at Lowestoft (e.g. https://www. youtube.com/watch?v=vTE5o3M7JF0). The estimated JL of the 5 December event ( 1 in 75 years) is estimated as substantially smaller than the HW return period (which was almost 1 in 200 years). This is because of a smaller $H_{\mathrm{S}}$ at the time of HW. The largest $H_{\mathrm{S}}$ during 2013/14 was at 22:30, 14 February 2014 at $3.94 \mathrm{~m}$, rated as a 1 in 5 year event (on the basis of the 30 year model hindcast). This did not occur during an extreme HW and hence was considered a flood threat on the east coast, although this particular storm caused flooding on the south coast of England. The largest $H_{\mathrm{S}}$ in the Sizewell wave buoy record is $4.72 \mathrm{~m}$, measured on 10 March 2008, again not associated with a big surge in Suffolk but also coincident with extreme sea levels and flooding on the south coast (Wadey et al., 2013). The largest wave period in the
Sizewell record (of 7.6 s) followed the Xaver Storm, during the night of 6-7 December 2013.

The 6 years of observed JL data assessed at Suffolk, and 11 years of (equivalent) data on the opposing UK coast at Sefton, indicated that the 5 December 2013 event was the most extreme of 2013/14, and within these data sets. Whilst return periods do not represent the actual or expected spacing between events (rather, they are the probability that the associated level for that return period will occur in a year), the values from the JOINSEA assessment were quite commensurate with a timeline perspective of damaging coastal impacts (at least compared to the sea level and wave return periods in their respective isolation). The Sefton data produced a JL of $>200$ years for 5 December 2013, and there is no record of a more severe flood or erosion event in living memory; hence such a large return period was plausible. In Suffolk, the same event was widely regarded as "the most serious surge and flood to hit the east coast for 60 years" (BBC, 2013b) - since 31 January 1953, therefore, the 1 in 75 year $\mathrm{JL}$ at Lowestoft was again proportionate with this statement.

\subsection{The temporal clustering of events}

The second objective, was to assess the temporal clustering and duration of extreme sea levels and waves. At Sefton, the assessment based upon the Liverpool tide gauge and wave buoy observations lists 14 instances of water level and/or wave extremes (above 1 in 1 year) during the 2013/14 season that resulted from six different storm periods. 2013/14 was the most extreme season for large sea-level events on record at Liverpool: there were six HWs above the 1 in 1 year return period, using the reference MSL of the year 2008; whereas with HW offset to remove the local MSL trend, there were five events above the 1 in 1 year level (Fig. 6). Previously the most extreme HW season was 2006/07. The season of 2013/14 ranks second for such HW clustering in the longer Heysham record (Fig. 6), with three events 


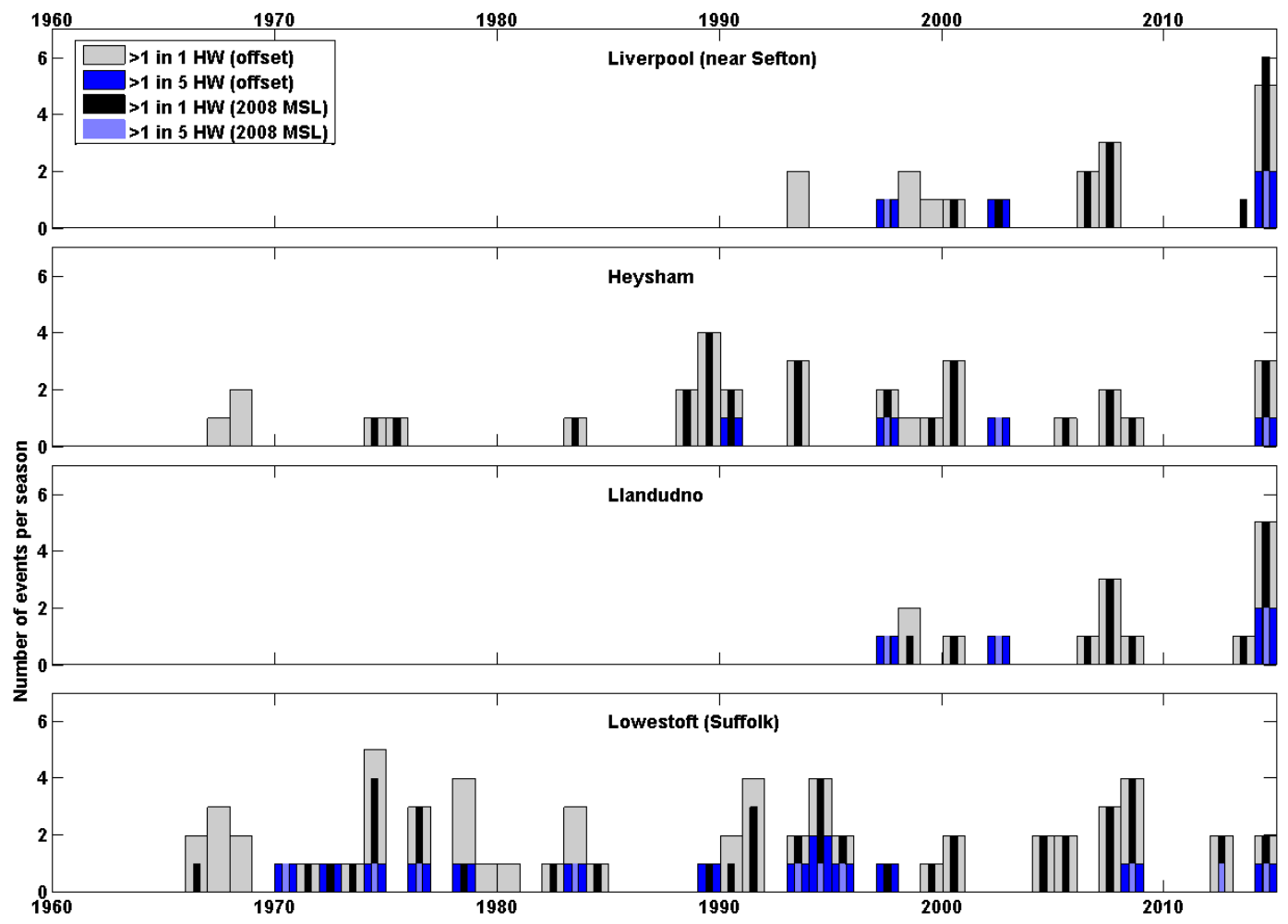

Figure 6. Seasonal high water event counts above the annual, and 1 in 5 year return periods (using return periods from McMillan et al., 2011a). This is shown relative to the 2008 mean sea level (MSL), and also offset for the local MSL trend (to illustrate how sea-level rise affects the timeline of extremes, especially in longer records).

above the 1 in 1 year level, which was surpassed by 1988/89 which saw four events above this threshold. When looking at the 1 in 5 year HW return period threshold, 2013/14 is the most extreme season at Liverpool and Llandudno, whilst at Heysham there has not yet been more than one event above this threshold per season. Interestingly, at Liverpool, sea level was above the 1 in 1 year threshold for a total of 5.3 non-consecutive hours during the 2013/14 season events the previous longest duration of exceedance was 2.25 nonconsecutive hours (2006/07). From the time series plot of wave height, period and 1 in 1 and 1 in 5 year $H_{\mathrm{S}}$ thresholds in Fig. 4, it is seen that 2013/14 does not stand out as particularly extreme in the 2002-2014 Liverpool wave record (Fig. 4a and b), with three instances of large $H_{\mathrm{S}}$ relating to separate storm events (using $>$ the 1 in 1 year return period from the 30 year hindcast data). The 2007/08 season was more clustered with five events above this threshold. The JL (i.e. JOINSEA HW- $H_{\mathrm{S}}$ level joint probability) assessment (Fig. 5) suggested 13 instances above the 1 in 1 year return period (seven which would not be considered extreme with $\mathrm{HW}$ or $H_{\mathrm{S}}$ assessed independently); the highest such seasonal cluster in this record (since 2002) - the previous maximum was 10 events above the 1 in 1 year level (in 2006/07). The 2013/14 season is even more extreme when it is considered that there were four events easily in excess of the 1 in 10 year return period (again the previous maxima was 2006/07, with only two above this level).

At Suffolk, the joint HW and $H_{\mathrm{S}}$ assessment, based upon the Lowestoft tide gauge and Sizewell wave buoy observations, respectively (Fig. 5, Table 3), identified nine extreme instances during the 2013/14 season that resulted from six different storms. In terms of water level, the HWs associated with the Xaver Storm (5-6 December 2013) were the only two during 2013/14 above the 1 in 1 year threshold; and only the first HW exceeded the 1 in 5 year threshold. The previous maximum number of HWs above the 1 in 1 year level (per season) was five in 1973/74; and in 1992/93 there were two HWs above the 1 in 5 year level (Fig. 6). Two events were also above a 1 in 1 year $H_{\mathrm{S}}$, but 2007/08 was more clustered with five events above this threshold. The JL probability suggested that nine events in the 2013/14 season were over the 1 in 1 year return period (two of which during 5-6 December 2013). Six of these events required the JL probability approach to define them as extreme (i.e. they were not extreme when sea level or wave height were assessed independently). 2013/14 was more clustered than the other years of February 2008 to July 2013, when there was previously a total of only four events above the 1 in 5 year return period (two of which were in March 2008). 

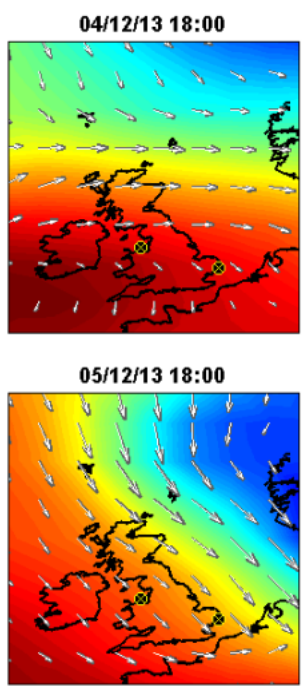

05/12/13 00:00

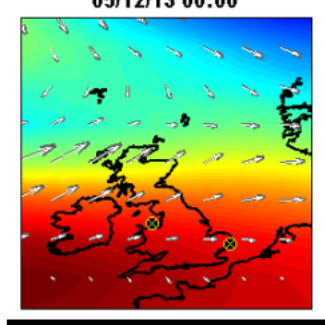

06/12/13 00:00

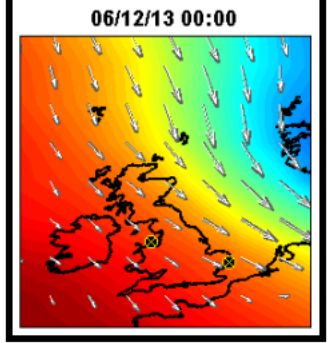

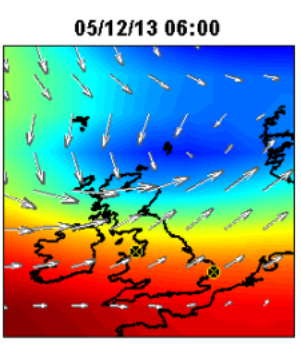

06/12/13 06:00

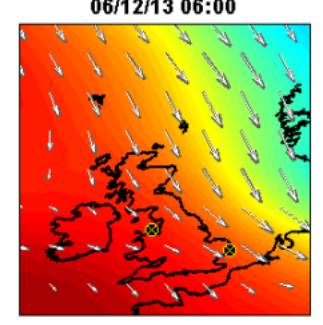

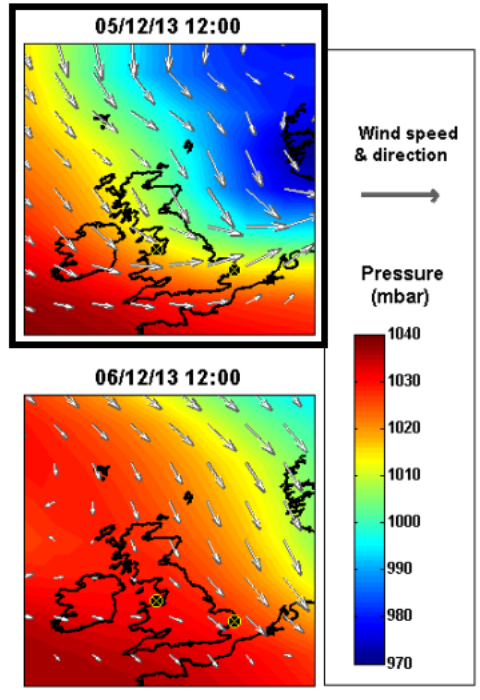

Figure 7. Time series of pressure and wind during 4-6 December 2013 - the locations of the Liverpool and Lowestoft tide gauges are shown, plotted from gridded surface wind and pressure data from the NCEP/NCAR reanalysis (Kalnay et al., 1996).

\section{Discussion}

\subsection{Comparison of the case study sites}

The third objective was to compare and contrast the case study sites. Starting with the sea-level analysis it was found that the Liverpool tide gauge in 2013/14 recorded a greater cluster of extreme sea-level instances: seven HWs were above the 1 in 1 year level, compared with only two events above this threshold at Lowestoft. Furthermore, at Liverpool the extreme HWs were spread out over time, from December to March; whereas both extreme HWs in Suffolk were on consecutive days, linked to the 5-6 December 2013 Xaver storm. The 5-6 December $2013 \mathrm{HW}$ at Lowestoft was far more extreme, at an almost 1 in 200 year return period, followed by a 1 in 1 year HW on the next tide, compared with a single 1 in 40 year HW at Liverpool. From a wave height perspective, the records are relatively short, and if waves are assessed independently from sea level, at neither location can 2013/14 be considered the most extreme at these sites.

Both sites have previously seen larger individual $H_{\mathrm{S}}$ events (03:30, 8 February 2004 at Liverpool, 10:30, 10 March 2008 at Sizewell) and more persistent seasons of large waves. It is noted this may not have been the case at other UK sites, whilst it is an assessment that excludes both wave period and event duration. The JL (joint HW and $H_{\mathrm{S}}$ probability) assessment gave very different event return periods at both sites, compared with taking $\mathrm{HW}$ and $H_{\mathrm{S}}$ return periods in isolation. This was most noticeable when the coincidence of $H_{\mathrm{S}}$ was taken into consideration for the 5 December event. This event was unusual for its national-scale impact, and is focused upon here as an example to discuss the different coastal responses to the same storm. This event was extreme nation- ally due to the timing of the storm and the veering winds over the UK, relative to high waters of the spring tide. At Liverpool the storm track allowed for extreme set-up of waves and surge, which due to the timing relative to the tide, created an extreme skew surge. The window of opportunity for an extreme HW and wave event at Liverpool is relatively limited, due to the large tidal range; whereas at Suffolk the surge is predominantly a long wave which has propagated from the northern North Sea, and at Lowestoft the relatively small tidal range allows for minimal tide-surge interaction, which allowed for two successive extreme HW events.

The biggest North Sea flood event in living memory, of 31 January 1953 was also associated with storminess in the Irish Sea (resulting in the sinking of the Princess Victoria, killing 133 people). However, flooding on the west coast during that event is not known of - one reason being that peak high tides were then at a smaller phase than they were during the storms of 5-6 December 2013. For the wide-scale flooding seen in December 2013, the storm track (that generated a surge in the North Sea) needed to coincide with spring tides on the west coast of the UK. However, at Sefton the waves on 5 December 2013 were not as extreme as is possible due to the rapid variation in wind direction, which caused time-limited wave growth - the winds veered $\mathrm{N}-\mathrm{NW}$ during the morning. Similarly, the waves and the wind component of surge in Suffolk were not as extreme as is possible - the wind was offshore at the time of HW (Fig. 7) and the low pressure centre did not track southwards as close to the coast as it did during the 1953 event. Storm tracks that are known to generate the most severe wind, wave and surge conditions in the Irish Sea are less likely to impact the North Sea, even if coincidental with spring tide. This is because SW-W fetches are associated with the worst conditions in the eastern Irish 

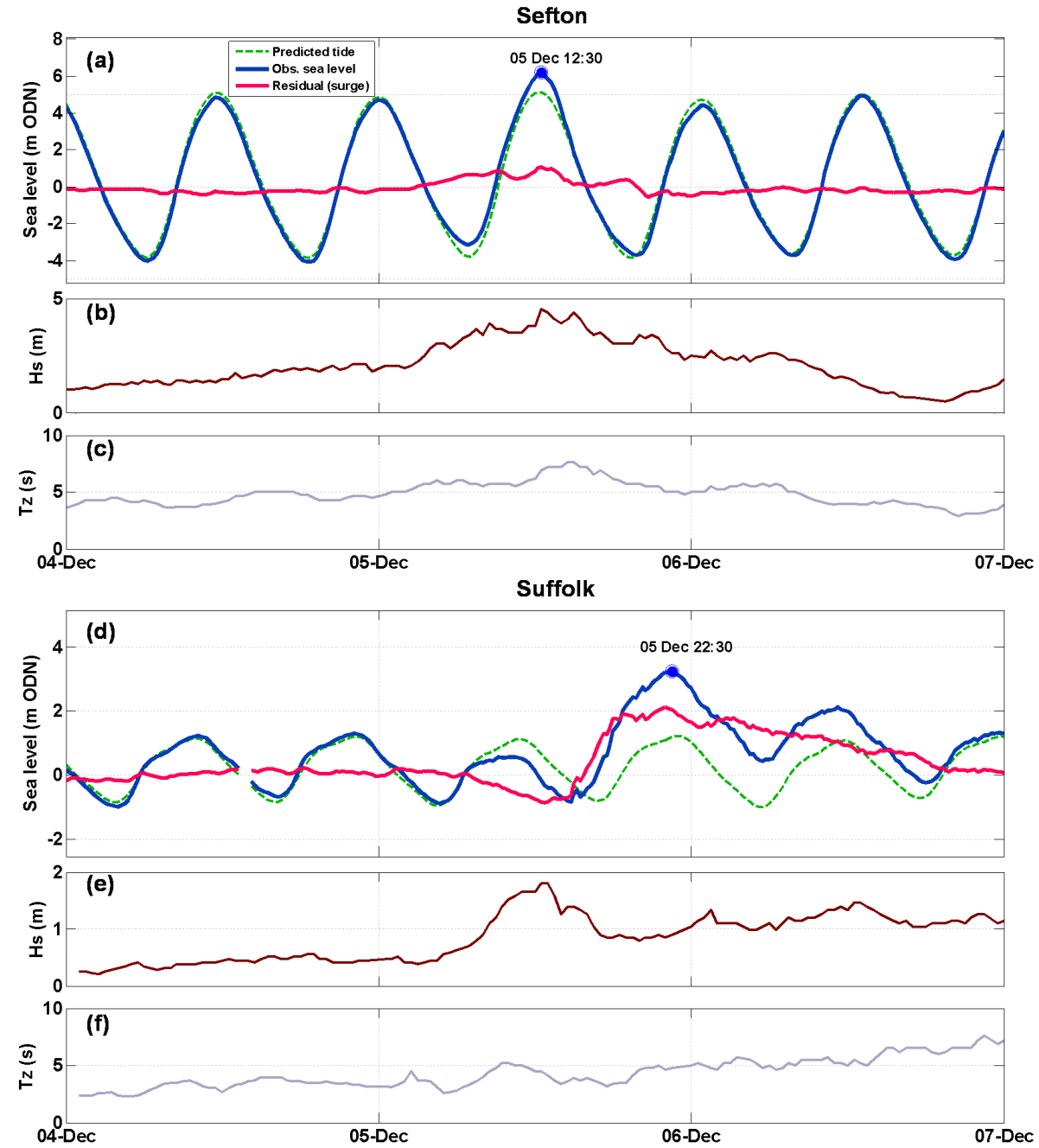

Figure 8. Observed sea level and wave time series during the 2013 Xaver storm (a) sea level, tide and surge, (b) significant wave height, (c) wave period; and for Suffolk (d) sea level, tide and surge (Lowestoft), (e) significant wave height, and (f) period (at Sizewell).

Sea, where the large $(>8 \mathrm{~m})$ tidal range controls extreme sea levels (Brown et al., 2010); whereas extreme sea-level events in the North Sea, especially at Lowestoft (with its small $2 \mathrm{~m}$ spring tidal range), are more determined by large storm surges. At Liverpool the coincidence of large waves on 5 December 2013 at the peak of the storm tide increased this event's extremity. Consideration of the HW level alone portrayed this as a 1 in 40 year event, which increased to beyond a 200 year return period with consideration of coincident $H_{\mathrm{S}}$. Contrastingly, at Lowestoft, the absence of extreme waves at the time of HW lowered the assessment of the event return period (an almost 1 in $200 \mathrm{HW}$, but a 1 in 75 year JL). At Liverpool both the surge (Fig. 8a) and large waves (Fig. 8b) peaked closely in time, due to the closer orientation of the fetches that generated these extreme conditions. These were coincident with the time of the peak astronomical tide (unusual but crucial due to the large tidal range, predicted at $8.9 \mathrm{~m}$ during this event). The waves and surge had dimin- ished by the next high tide. It is noted that the second most extreme 2013/14 event at Sefton, the 1 in 75 year joint waterwave level occurrence on 3 January 2014, was much smaller ( $0.36 \mathrm{~m}$ lower peak HW, and $H_{\mathrm{S}}$ of approx. half the size of 5 December 2013), but did cause coastal damage at Sefton because of the magnitude of the tide and waves that persisted for several days (i.e. until the 6 January - Table 2).

At Lowestoft, the situation on the 5-6 December 2013 contrasted with that of Sefton because the surge component is as large as the tidal range (approx. $2 \mathrm{~m}$ ). The surge was also more prolonged than at Liverpool: the non-tidal residual (primarily consisting of storm surge) remained at $>1 \mathrm{~m}$ over two tidal cycles and for over $18 \mathrm{~h}$, which is why the morning high water of 6 December was also extreme. Unlike at Sefton, the waves and surge were not as coupled, with the peak $H_{\mathrm{S}}$ occurring around midday due to the SW winds, dropping by the time the surge and tide had propagated into the North Sea causing a peak in water level at the same location, but 
this time under NE wind conditions. While the surge levels dropped after HW, the waves recorded at Sizewell begin to build again (as the wind direction at the Suffolk coast aligns from NW towards the N) causing a second extreme JL. However, if the local wind had been stronger and more northerly during the 5 December evening HW, this could have both added to the surge height and wave conditions - an onshore storm (as in 1953) would have caused more severe damage (e.g. SDC, 2014). The bimodal wave climate at this location led to the multiple instances of large wave events as the storm winds veered from SW to N. During SW wind-wave events, this location is unlikely to experience large surge levels; the joint occurrence of large waves and surge is more likely to occur during NW to NE-veering winds. In this case the slow veering of the winds towards a more northerly direction delayed the secondary peak in waves coinciding with the peak surge level.

\subsection{Coastal defence performance}

The fourth objective was to discuss, in relation to the analysis presented here and general reports of flooding and damage, how the coastal defences at these case studies performed. We reiterate that the return periods shown should be treated with caution due to the short length of the data sets that were applied. Return periods inevitably change with new data (and further extreme events) and different analysis methods. Further challenges include that detail of the defences (e.g. structural design and condition assessments) were not available; and that the case studies contain naturally variable systems (e.g. beach levels, offshore bars, intertidal mudflats) which provide defence (and are not incorporated into our assessment). The defences and floodplain between the two case study regions are fundamentally quite different, hence failure of defences can have different implications. There are larger areas (immediately behind defences) of land below extreme sea levels in Suffolk; hence breach defence failures can cause particularly dangerous inundation (as in 1953), whereas at Sefton, the natural and engineered defences are located just above mean spring HW, and consequences of extreme events tend to be measured more in terms of erosion and overtopping.

The UK's coast is extensively managed via a risk-based approach, which includes aiming for specified standards of protection at different locations, based upon the potential consequences (e.g. property losses, risk to life) of defence failure. The cost benefit or risk analysis would typically use design conditions referenced to hydraulic load(s) (e.g. river flow, storm-tide level or wave height) return period. Nationally standardised protection followed the Waverley Report in response to the 1953 floods, whereby flood defences were set to withstand a 1 in 100 year still water level (Alcock, 1984). Coastal flood defence design standards are (since approx. 1980s) more commonly based upon joint sea level and wave conditions, and are often between 50 and 100 years (cf. Hames and Reeve, 2007). These standards require defences to limit damage and overtopping from storms to a level that will be reached or exceeded on average once during a period matching the design standard. Implied in more recent risk management and insurance policy is that coastal flood defence schemes should not breach (i.e. collapse or break open) given a 1 in 200 year "tidal event" (DCLG, 2009), although wave overtopping onto promenades and sea walls and "localised flooding" is often accepted. Design standards for some areas are more stringent, for example a 1 in 1000 year level for London (e.g. Ramsbottom et al., 2006) and 1 in 10000 for nuclear power stations (e.g. Wilby et al., 2011). The indicative "tidal" floodplain in which risk is managed by the EA, and the most frequently used categorisation in planning and flood management is typically defined by an envelope of land that is exposed (i.e. would flood without defences) to a 1 in 200 year annual probability flood (EA, 2009). Meanwhile "Flood Re", a fund to provide affordable flood cover to high risk properties, will pay out on reinsurance claims up to the limit equivalent to a 1 in 200 year level of claims (Defra, 2013).

In the Sefton region, the largest return period HW at Liverpool on 5 December 2013 was approx. 40 years, but when considering coincidental $H_{\mathrm{S}}$, the analysis indicated the event JL was $>200$ years. This event overtopped and damaged (but did not breach) natural and man-made defences, and caused some coastal flooding. Observed erosional storm impacts were the most severe in living memory, the loss of duneland exceeding that of the last major event in February 1990 when the National Trust frontage lost $13.6 \mathrm{~m}$ (Smith, 2014). Less than a month later, the 3 January 2014 was an approx. 75 year $\mathrm{JL}$ and also caused damage. As the analysis indicated, the 2013/14 winter contained more extreme events than any other season on record, a likely contributor to the coastal retreat of the 2013/14 winter being greater than the cumulative erosion experience over the previous 5 years. Survey data (taken 8 October 2014) show that the system had not recovered by summer 2014. A moderate HW combined with large waves has been noted to damage defences at Sefton; notably the dune systems are vulnerable when there is a lack of recovery time between erosion events (Esteves et al., 2012). Given the previously unseen cluster of extreme events of 2013/14, the defences stood up well. With the Crosby sea wall at Sefton nearing the end of its design life and a new scheme to be implemented in the next 10 years, this assessment indicates levels that these defences were already resilient to.

In Suffolk during the 5 December event, some sections of defence failed to prevent flooding (e.g. at Lowestoft see Sect. 2 of this paper), including structural breaches. The 5 December 2013 HW at Lowestoft was an almost a 1 in 200 year occurrence, although the JL assessment (with Sizewell $H_{\mathrm{S}}$ ) indicated a 1 in 75 year event. The $1953 \mathrm{HW}$ at Lowestoft was 1 in 270 years at 2008 MSL, increasing to 1 in 400 years when offset for MSL change; although the wave conditions that coincided with the 1953 surge (e.g. Flather, 
1984; Wolf and Flather, 2005; Spencer et al., 2015) were much larger, and would not have reduced (and more likely increased) the JL return period in the same way as those of the 2013 event. However, since river levels were not included in this assessment, it is important to differentiate between open coast and tidal-river/estuary locations. There was overtopping on 5-6 December 2013 due to the extreme sea level (with waves superimposed upon it), but most open coast defences (which had failed in 1953) held, and prevented serious flooding. However, the 2013 event did cause floods, for example around the Oulton Broad (a location sheltered from waves and where the River Waveney flows into Lake Lothing), and the inner harbour areas of Lowestoft. Other reported breaches (e.g. including those which affected Waldringfield and Ipswich) were on the tidal Deben and Orwell rivers. To properly assess the return period of the sea levels at these locations (in an equivalent way that $H_{\mathrm{S}}$ supplemented the open coast event assessments) river level data would also be required. Interestingly, Steers (1953) remarked that the 31 January 1953 flood would have been much worse in the Anglia regions if river levels had been high (which at the time they were not). At Sizewell, flooding and erosion are concerns for the nuclear sites. Currently the ground upon which these lie is protected by a two-layered line of defences (Magnox, 2014), and the site for the proposed Sizewell $\mathrm{C}$ development is approx. $3 \mathrm{~m}$ above the level of the 5 December $2013 \mathrm{HW}$ (EDF Energy, 2012). The surrounding land is low-lying, and during the December 2013 event, the sea broke over the coastal dunes just south of the Dunwich cliff, but did not breach the nearby Minsmere dunes (as it did in 1953).

The UK's 2013/14 winter was exceptionally stormy (Met Office, 2014; Matthews et al., 2014) and fell during a high period of the 18.6 year and 4.4 year interannual tidal cycles (Haigh et al., 2011; Wadey et al., 2014) - the season saw the highest average HW level at both regions. There is uncertainty over MSL projections (Church et al., 2013) and storm patterns (Zappa et al., 2013). However, ongoing mean SLR is increasing the frequency of extreme sea levels and as shown here, it is important to consider offsetting for this, to assess the extremity of individual storm tide, and determine meaningful storm-driven design thresholds to assess future defence performance (i.e. as defences are upgraded whilst SLR is occurring). As wave records become longer, offsetting of sea level in the joint sea level-wave analysis will have a greater effect; and with changing climate there is a potential for changes to wave severity - if trends in wave height become significant then a suitable offset should also be considered. Other research has highlighted that not only are the number of storms within a given space of time important to coastal impacts (such as erosion and flooding), but also the characteristics (e.g. duration) of each storm. On the English south coast, consecutive HW events during December 1989 were correlated with the worst flooding on record, despite not generating the most extreme sea levels (Ruocco et al., 2011). Furthermore, weather-ocean-wave-overtopping modelling by Zou et al. (2013) describes how magnitude, time and location of sea wall overtopping predictions deviated considerably amongst ensemble members. This illustrates a complex and important relationship between overtopping discharges, wave fields and different storm characteristics (which can be highly variable, e.g. due to the forward speed and translation speed of the storm). Storm duration has also been noted as a critical parameter for investigating wave climate and dune erosion (Li et al., 2013); and at the Sefton case study, Dissanayake et al. (2015) suggested that duration of wave activity (rather than wave magnitude) above a water level threshold may be a more important factor in shore-face erosion. Another source of temporal influence upon coastal flood risk is variability in observed still water level time series (Quinn et al., 2014), a result of tide and non-tidal (including site specific) characteristics.

\section{Conclusions}

In this paper, the extremity of the 2013/14 "storm season" was assessed for two case studies (Sefton, northwest coast; Suffolk, east coast), from a perspective that could, for example, help to inform coastal managers who have to plan for defence upgrades. The first objective was to use and generate return periods to catalogue instances of extreme high water $(\mathrm{HW})$, significant wave height $\left(H_{\mathrm{S}}\right)$ and the joint level (JL) probability (of HW and $H_{\mathrm{S}}$ ). The second objective was to assess temporal clustering of extremes, as determined by counting $\mathrm{HW}, H_{\mathrm{S}}$ and JL above an annual return period threshold, and how many of these events fell within annual storm seasons across the data sets. At Liverpool (the site used to assess Sefton), 2013/14 produced the largest HW within the 22 year data set (40 year return period), on 5 December 2013. At Lowestoft (the tide gauge site used to assess Suffolk case study), the same storm-tide event produced the largest HW in a 40 year data set (200 year return period), although this was smaller than the HW of 31 January 1953. The magnitude of event return periods changed substantially (and differently for each case study) when HW and $H_{\mathrm{S}}$ were considered independently compared to when they were considered together. The 5 December 2013 event at Liverpool was upgraded from a 1 in $40 \mathrm{HW}$ to a 1 in 200 year JL, which was actually more extreme than this event had been in Suffolk (where it was downgraded from a 1 in 200 year HW to a 1 in 75 year JL). At Liverpool the 2013/14 season produced more extreme HWs (above the 1 in 1 and 1 in 5 year thresholds) that any other season (five HWs above the annual threshold and two above the 1 in 5 threshold). At Lowestoftm 2013/14 was less distinctive as such a seasonal extreme HW cluster. The $H_{\mathrm{S}}$ and JL probability assessment identified further extreme events (than considering HWs alone): at Liverpool there were 14 incidences above the annual probability and in Suffolk there were nine incidences. 
The third and fourth objectives were to compare the two case studies and discuss defence performance during 2013/14. At Suffolk, only the 5 December 2013 was notable as a coastal flood/erosion event during this season, whereas the 3 January 2014 also impacted Sefton. At Sefton, the $\mathrm{JL}$ assessment suggested that the season was both more extreme for individual events, and more clustered than at Suffolk. However, the consequences of large storm tides is a greater threat to life in Suffolk (e.g. as shown by 1953). Any commentary upon defence performance is limited by the length of the data sets and detail of defence failures. However, the analysis shows that the stand-out event of the season, 5 December 2013, was an outlier in both case study regions, and the tidal and meteorological conditions allowed for a national-scale coastal impact. The defences appear to have performed as expected in the context of the different joint probability assessments; although in Suffolk, river levels during 5-6 December 2013 were likely to have been important to the inland defence responses - inclusion of this within joint probability and clustering assessments is recommended for future work. Engineered schemes in both of the case study locations vary in their design; thus defining storm event severity at a location (such as in this study) can allow the robustness of different designs to be monitored to inform future plans to optimise engineered structures.

As noted in Sect. 2, coastal processes in England and Wales are often considered on a regional basis for shoreline management. Hence it is recommended that for this, and more local management, that flood and erosion incidences are monitored and catalogued alongside sea level and wave analysis, so that event-driven and long-term coastal response to storms at any given site can be understood. This would allow a better interpretation of the relationship between storm severity and long-term repeat impact and interstorm recovery, which influences the long-term geomorphology of a system (Plater and Grenville, 2010). Storm impacts can control regional sediment supply (e.g. via regional cliff erosion), influence geomorphology and structural integrity. If a change in state occurs due to a storm it is important to identify whether this was a consequence of a temporal cluster in events or a single extreme event, to understand how events could cause impact on similar natural systems (e.g. the dunes at the Sefton are important features that respond to repeated loads; in other places state changes may happen to other features such as rip channels). This case study was enhanced by using all three methods (assessing sea levels and wave independently, and combined), allowing a comprehensive list of events for which loads can be associated with storm damages across multiple years; whilst maximising the full length of the respective observed data sets and where they overlap. Categorising storms is of interest for research, for example, Dissanayake et al. (2015) used the 5 December 2013 event and two other events that month to model storm impacts that occur between the biannual shoreline survey intervals. Individual extreme events such as 5 December 2013 stand out, although as noted in Sect. 5, sequences and duration of storms are also important. Therefore future work to statistically analyse storm events could benefit from methods which can incorporate more parameters (including also those previously mentioned such as river levels) (Wahl et al., 2012).

This type of assessment furthers the information available to local managers about individual and cumulative storm impacts. Analysis of sea level and wave extremes, associated with defence performance and natural system changes over time, can complement development of new management approaches and schemes for coastal protection. Joint probabilities are widely used in flood planning, and science-informed management can be a standpoint for government and coastal managers when targeting improvements to long-term resilience. It is recommended that in further work, return periods are regularly updated to incorporate new data and methods. This, in combination with sea level and wave observations, can be used to systematically compare the extremity and duration of loads on defences between past events and winter storm seasons - and ideally would be accompanied by a time series which records targeted defence standards, upgrades, damage and repair.

Acknowledgements. We thank the following: British Oceanographic Data Centre and National Tide and Sea Level Facility (sea-level data); the Environment Agency (return period statistics); CEFAS and Met Office (wave hindcast data). All the authors were funded through the Engineering and Physical Science Research Council Flood Memory Project (grant number EP/K013513/1), and Jenny Brown also through EPSRC ACRoES (Adaptation and Resilience to Coast Energy Supply) project, grant no: EP/103590/1.

Edited by: A. Plater

Reviewed by: two anonymous referees

\section{References}

Alcock, G.: Parameterizing extreme still water levels and waves in design level studies, Report No. 183, Institute of Oceanographic Sciences, available at: http://eprints.soton.ac.uk/14599/ 1/14599-01.pdf (last access: 5 February 2015), 1984.

Araújo, I. B. and Pugh, D. T.: Sea Levels at Newlyn 1915-2005: Analysis of Trends for Future Flooding Risks, J. Coastal Res., 24, 203-212, 2008.

Batstone, C., Lawless, M., Tawn, J., Horsburgh, K., Blackman, D., McMillan, A., Worth, D., Laeger, S., and Hunt, T.: A UK bestpractice approach for extreme sea-level analysis along complex topographic coastlines, Ocean Eng., 71, 28-39, 2013.

Baxter, P. J.: The east coast Big Flood, 31 January-1 February 1953: a summary of the human disaster, Phil. T. Roy. Soc. A: Mathematical, Physical and Engineering Sciences, 363, 1293-1312, 2005.

BBC: Suffolk flooding: Shingle Street sea wall repairs underway, 12 December 2013, last updated at 02:14, available at: http://www. bbc.co.uk/news/uk-england-suffolk-25343116 (last access: 15 January 2015), 2013a. 
BBC: Tidal surge hits east UK coastal towns after storm, 6 December 2013 , last updated at 17:19, available at: http://www.bbc.co. uk/news/uk-25253080 (last access: 3 February 2015), $2013 \mathrm{~b}$.

BBC: 10 key moments of the UK winter storms, 17 February 2014, BBC News. available at: http://www.bbc.co.uk/news/ uk-26170904 (last access: 15 January 2015), 2014a.

BBC: Channel Islands flooded after 'highest tide of the year', 3 March 2014, BBC News, Jersey, available at: http://www.bbc.co. uk/news/world-europe-jersey-26390204 (last access: 15 January 2015), 2014b.

Bradley, S. L., Milne, G. A., Teferle, F. N., Bingley, R. M., and Orliac, E. J.: Glacial isostatic adjustment of the British Isles: new constraints from GPS measurements of crustal motion, Geophys. J. Int., 178, 14-22, 2009.

Brown, J. M., Souza, A. J., and Wolf, J.: An investigation of recent decadal-scale storm events in the eastern Irish Sea, J. Geophys. Res., 115, C05018, doi:10.1029/2009JC005662, 2010.

Church, J. A. and White, N. J.: A 20th century acceleration in global sea-level rise, Geophys. Res. Lett., 33, L01602, doi:10.1029/2005GL024826, 2006.

Church, J. A., Clark, P. U., Cazenave, A., Gregory, J. M., Jevrejeva, S., Levermann, A., Merrifield, M. A., Milne, G. A., Nerem, R. S., Nunn, P. D., Payne, A. J., Pfeffer, W. T., Stammer, D., and Unnikrishnan, A. S.: Sea level change, in: Climate Change 2013: the Physical Science Basis. Contribution of Working Group I to the Fifth Assessment Report of the Intergovernmental Panel on Climate Change, edited by: Stocker, T. F., Qin, D., Plattner, G.K., Tignor, M., Allen, S. K., Boschung, J., Nauels, A., Xia, Y., Bex, V., and Midgley, P. M., Cambridge Univer5 sity Press, Cambridge, UK and New York, NY, USA, 1137-1216, 2013.

Coles, S. G. and Tawn, J. A.: Statistics of coastal flood prevention, Phil. T. Roy. Soc. London-Series A: Physical and Engineering Sciences, 332, 457-476, 1990.

Cooper, N. and Pontee, N.: Appraisal and evolution of the littoral 'sediment cell' concept in applied coastal management: experiences from England and Wales, Ocean Coast. Manag., 49, 498510, 2006

DCLG: Planning Policy Statement 25: Development and Flood Risk Practice Guide, December 2009, Department for Communities and Local Government, available at: https://www.gov.uk/government/uploads/system/uploads/ attachment_data/file/7772/pps25guideupdate.pdf (last access: 3 February 2015), 2009.

Defra: Water Bill: Flood Insurance, November 2013, Department for Environment, Food and Rural Affairs, available at: https: //www.gov.uk/government/uploads/system/uploads/attachment_ data/file/259665/pb14066-water-bill-flood-insurance.pdf (last access: 3 February 2015), 2013.

Dissanayake, P., Brown, J., and Karunarathna, H.: Modelling storminduced beach/dune evolution: Sefton coast, Liverpool Bay, UK, Marine Geol., 357, 225-242, 2014.

Dissanayake, P., Brown, J., and Karunarathna, H.: Impacts of storm chronology on the morphological changes of the Formby beach and dune system, UK, Nat. Hazards Earth Syst. Sci., 15, 15331543, doi:10.5194/nhess-15-1533-2015, 2015.

Dolphin, T., Vincent, C., Coughlan, C., and Rees, J.: Variability in sandbank behaviour at decadal and annual time-scales and implications for adjacent beaches, J. Coast. Res., 50, 731-737, 2007.
EA: Flooding in England: A National Assessment of Flood Risk, Environment Agency, available at: http://publications. environment-agency.gov.uk/PDF/GEHO0609BQDS-E-E.pdf (last access: 14 April 2015), 2009.

EADT: Sizewell C: Scientists probing N-plant flood threat, available at: http://www.eadt.co.uk/business/sizewell_c_scientists_ probing_n_plant_flood_threat_1_1811534 (last access: 3 December 2014), 2013.

EDF Energy: Sizewell C: Initial Proposals and Options Consultation Document, November 2012, available at: http://sizewell.edfenergyconsultation.info/wp-content/uploads/ Consultationdocument.pdf (last access: 2 September 2015), 2012.

Esteves, L. S., Brown, J. M., Williams, J. J., and Lymbery, G.: Quantifying thresholds for significant dune erosion along the Sefton Coast, Northwest England, Geomorphology, 143, 52-61, 2012.

Flather, R. A.: A numerical model investigation of the storm surge of 31 January and 1 February 1953 in the North Sea, Q. J. Roy. Meteorol. Soc., 110, 591-612, 1984.

Gerritsen, H.: What happened in 1953? The Big Flood in the Netherlands in retrospect, Phil. T. Roy. Soc. A: Mathematical, Physical and Engineering Sciences, 363, 1271-1291, 2005.

Gönnert, G., Dube, S. K., Murty, T. S., and Siefert, W.: Global Storm Surges: Theory Observation and Applications, German Eng. Res. Council, 63, 623 p., 2001.

Haigh, I., Nicholls, R., and Wells, N.: Assessing changes in extreme sea levels: Application to the English Channel, 1900-2006, Cont. Shelf Res., 30, 1042-1055, 2010.

Haigh, I. D., Eliot, M., and Pattiaratchi, C.: Global influences of the 18.61 year nodal cycle and 8.85 year cycle of lunar perigee on high tidal levels, J. Geophys. Res., 116, C06025, doi:10.1029/2010JC006645, 2011.

Hames, D. and Reeve, D.: The joint probability of waves and high sea levels in coastal defence, in: Proceedings of Flood Risk Assessment II Conference, 09-04 2nd IMA International Conference on Flood Risk Assessment, 4-5 September 2007, Institute of Mathematics \& Its Applications, University of Plymouth, 97 106, available at: http://www.ima.org.uk/viewItem.cfm-cit_id= 383896.html (last access: 4 April 2015), 2007.

Hanson, S., Nicholls, R., Ranger, N., Hallegatte, S., Corfee-Morlot, J., Herweijer, C., and Chateau, J.: A global ranking of port cities with high exposure to climate extremes, Clim. Change, 104, 89111,2011

Hawkes, P. and Gouldby, B.: The joint probability of waves and water levels, JOINSEA-User Manual, HR Wallingford, Wallingford, UK, 1998.

Hawkes, P. and Svensson, C.: Joint Probability: Dependence mapping and best practice, Defra/Environment AGency R \& D Interim Technical Report FD2308/TR1, HR Wallingford, UK, 120 p., 2003.

Hawkes, P. J., Gouldby, B. P., Tawn, J. A., and Owen, M. W.: The joint probability of waves and water levels in coastal engineering design, J. Hydraul. Res., 40, 241-251, 2002.

Heaps, N. S.: Storm surges, 1967-1982, Geophys. J. Roy. Astron. Soc., 74, 331-376, 1983.

Horsburgh, K. J. and Wilson, C.: Tide-surge interaction and its role in the distribution of surge residuals in the North Sea, J. Geophys. Res., 112, 1-13, 2007. 
Kalnay, E., Kanamitsu, M., Kistler, R., Collins, W., Deaven, D., Gandin, L., Iredell, M., Saha, S., White, G., and Woollen, J.: The NCEP/NCAR 40-year reanalysis project, B. Am. Meteorol. Soc., 77, 437-471, 1996.

Lamb, H.: Historic storms of the North Sea, British Isles and Northwest Europe, Cambridge 30 University Press, Cambridge, 1991.

Lennon, G.: The identification of weather conditions associated with the generation of major storm surges along the west coast of the British Isles, Q. J. Roy. Meteorol. Soc., 89, 381-394, 1963.

Leonard-Williams, A. and Saulter, A.: Comparing EVA results from analysis of 12 years of WAVEWATCH III $^{\mathrm{TM}}$ and 50 years of NORA10 data. Forecasting Research Technical Report No: 574, available at: http://www.metoffice.gov.uk/media/pdf/8/ 3/FRTR574.pdf (last access: January 2014), 2013.

Li, F., Van Gelder, P. H. A. J. M., Callaghan, D. P., Jongejan, R. B., Den Heijer, C., and Ranasinghe, R.: Probabilistic modeling of wave climate and predicting dune erosion, J. Coast. Res. Spec. Issue, 65, 760-765, 2013.

Magnox: Sizewell A Site Strategic Environmental Assessment, Site Specific Baseline, September 2014, Magnox Ltd, available at: https://magnoxsites.com/wp-content/uploads/2014/11/ Sizewell-A-SEA-FINAL.pdf (last access: 2 September 2015), 2014.

Matthews, T., Murphy, C., Wilby, R. L., and Harrigan, S.: Stormiest winter on record for Ireland and UK, Nature Clim. Change, 4, 738-740, 2014.

McMillan, A., Batstone, C., Worth, D., Tawn, J. A., Horsburgh, K., and Lawless, M.: Coastal flood boundary conditions for UK mainland and islands, Project SC060064/TR2, Design sea levels, Environment Agency, Bristol, UK, 2011a.

McMillan, A., Johnson, A., Worth, D., Tawn, J. A., and Hu, K.: Coastal flood boundary conditions for UK mainland and islands, Project SC060064/TR3, Design swell waves, Environment Agency, Bristol, UK, 2011 b.

McRobie, A., Spencer, T., and Gerritsen, H.: The Big Flood: North Sea storm surge, Phil. T. Roy. Soc. A: Mathematical, Physical and Engineering Sciences, 363, 1263-1270, 2005.

Menéndez, M. and Woodworth, P. L.: Changes in extreme high water levels based on a quasi-global tide-gauge data set, J. Geophys. Res., 115, C10011, doi:10.1029/2009JC005997, 2010.

Met Office: Winter storms, December 2013 to January 2014, Online report, available at: http://www.metoffice.gov.uk/climate/uk/ interesting/2013-decwind (last access: 3 February 2015), 2014.

Motyka, J. M. and Brampton, A. H.: Coastal management: mapping of littoral cells, HR Wallingford Report SR328, 1993.

NT: How have the storms affected the coast? The National Trust - coast \& countryside, available at: http://www.nationaltrust.org. uk/article-1355824158683/, last access: 6 November 2014.

Plater, A. J. and Grenville, J.: Liverpool Bay: Linking the eastern Irish Sea to the Sefton Coast, in: Sefton's Dynamic Coast, edited by: Worsley, A. T., Lymbery, G., Holden, V. J. C., and Newton, M., Coastal Defence: Sefton MBC Technical Services Department, Ainsdale-on-Sea, Southport, p. 28-54, ISBN 9780-9566350-0-6, 2010.

Pugh, D. T.: Tides, surges and mean sea-level. A handbook for engineers and scientists, Wiley, Chichester, 2004.

Pye, K. and Blott, S. J.:. Coastal processes and morphological change in the Dunwich-Sizewell area, Suffolk, UK, J. Coast. Res., 22, 453-473, 2006.
Pye, K. and Blott, S.: Decadal-scale variation in dune erosion and accretion rates: an investigation of the significance of changing storm tide frequency and magnitude on the Sefton coast, UK, Geomorphology, 102, 652-666, 2008.

Pye, K. and Blott, S. J.: Progressive Breakdown of a GravelDominated Coastal Barrier, Dunwich-Walberswick, Suffolk, UK.: Processes and Implications, J. Coast. Res., 25, 589-602, 2009.

Quinn, N., Lewis, M., Wadey, M., and Haigh, I.: Assessing the temporal variability in extreme storm-tide time series for coastal flood risk assessment, J. Geophys. Res.-Oceans, 119, 49834998, 2014.

Ramsbottom, D., Tarrant, O., and Cooper, A.: Sources of flooding on floodplains of the tidal Thames, HR Wallingford, available at: http://eprints.hrwallingford.co.uk/63/1/HRPP325_Sources_of_ flooding_on_floodplains_of_the_tidal_Thames.pdf (last access: 3 February 2015), 2006.

Rossiter, J. R.: The North Sea Storm Surge of 31 January and 1 February 1953, Phil. T. Roy. Soc. London Series A, Mathematical and Physical Sciences, 246, 371-400, 1954.

Royal Haskoning: SUFFOLK SMP2 Sub-cell 3c, Policy Development Zone 3 - Easton Broad to Dunwich Cliffs. Available online: http://www.suffolksmp2.org.uk/publicdocuments/finalsmp/ Section\%204_Policy\%20Development\%20Zones/PDZ3v9.pdf (last access: 4 February 2015), 2010.

Ruocco, A., Nicholls, R., Haigh, I., and Wadey, M.: Reconstructing coastal flood occurrence combining sea level and media sources: a case study of the Solent, UK since 1935, Nat. Hazards, 59, 1773-1796, 2011.

SDC: East Coast Tidal Surge - 5 \& 6 December 2013, available at: http://www.suffolkcoastal.gov.uk/yourdistrict/planning/ coastal-management/tidalsurge/, last access: 28 October 2014.

SFCN: 1. December Tidal Surge, available at: http://www.greensuffolk.org/assets/ Greenest-County/Coastal/Suffolk-Flood--Coastal-News/ Suffolk-Flood-and-Coastal-News-Feb-2014.pdf, last access: 29 October 2014.

Shennan, I. and Horton, B.: Holocene land- and sea-level changes in Great Britain, J. Quat. Sci., 17, 511-526, 2002.

Smith, P. H.: Effects of winter storm surges on the Sefton Coast, north Merseyside, Sand Dune and Shingle Network Eighteenth Newsletter, March 2014, Linking science and management, Liverpool Hope University, available at: http://coast.hope.ac.uk/media/liverpoolhope/contentassets/ images/coast/media,38794,en.pdf, last access: 6 Novermber 2014.

Spencer, T., Brooks, S. M., Evans, B. R., Tempest, J. A., and Möller, I.: Southern North Sea storm surge eventof 5 December 2013: Water levels, waves and coastal impacts, Earth-Sci. Rev., 146, 120-145, 2015.

Steers, J. A.: The East Coast Floods, January 31-February 11953 , Geographical J., 119, 280-295, 1953.

Stevens, A. J., Clarke, D., and Nicholls, R. J.: Trends in reported flooding in the UK: 1884-2013, Hydrol. Sci. J., doi:10.1080/02626667.2014.950581, 2014.

Stevens, A. J., Clarke, D., Nicholls, R. J., and Wadey, M. P.: Estimating the long-term historic evolution of exposure to flooding of coastal populations, Nat. Hazards Earth Syst. Sci., 15, 12151229, doi:10.5194/nhess-15-1215-2015, 2015. 
Tucker, M., Carr, A., and Pitt, E.: The effect of an offshore bank in attenuating waves, Coastal Eng., 7, 133-144, 1983.

Wadey, M. P., Nicholls, R. J., and Haigh, I.: Understanding a coastal flood event: the 10th March 2008 storm surge event in the Solent, UK, Nat. Hazards, 67, 829-854, 2013.

Wadey, M. P., Haigh, I. D., and Brown, J. M.: A century of sea level data and the UK's 2013/14 storm surges: an assessment of extremes and clustering using the Newlyn tide gauge record, Ocean Sci., 10, 1031-1045, doi:10.5194/os-10-1031-2014, 2014.

Wadey, M. P., Cope, S. N., Nicholls, R. J., McHugh, K., Grewcock, G., and Mason, T.: Coastal flood analysis and visualisation for a small town, Ocean Coast. Manag., 116, 237-247, 2015.

Wahl, T., Jensen, J., Frank, T., and Haigh, I.: Improved estimates of mean sea level changes in the German Bight over the last 166 years, Ocean Dynam., 61, 701-715, 2011.

Wahl, T., Mudersbach, C., and Jensen, J.: Assessing the hydrodynamic boundary conditions for risk analyses in coastal areas: a multivariate statistical approach based on Copula functions, Nat. Hazards Earth Syst. Sci., 12, 495-510, doi:10.5194/nhess-12495-2012, 2012.

Wilby, R., Nicholls, R., Warren, R., Wheater, H., Clarke, D., and Dawson, R.: New nuclear build: adaptation options over the full life-cycle, Proc. Inst. Civil Eng., 164, 129-136, 2011.
Wirral Council: Flood investigation report for 5 December 2013, available online: http://www.wirral.gov. uk/my-services/advice-and-benefits/emergencies/floods/ flood-monitoring-and-reports, last access: 13 November 2014.

Wolf, J. and Flather, R. A.: Modelling waves and surges during the 1953 storm, Phil. T. Roy. Soc. A: Mathematical, Physical and Engineering Sciences, 363, 1359-1375, 2005.

Woodworth, P., Teferle, F. N., Bingley, R., Shennan, I., and Williams, S.: Trends in UK mean sea level revisited, Geophys. J. Int., 176, 19-30, 2009.

Zappa, G., Shaffrey, L. C., Hodges, K. I., Sansom, P. G., and Stephenson, D. B.: A Multimodel Assessment of Future Projections of North Atlantic and European Extratropical Cyclones in the CMIP5 Climate Models*, J. Climate, 26, 5846-5862, 2013.

Zou, Q. P., Chen, Y., Cluckie, I., Hewston, R., Pan, S., Peng, Z., and Reeve, D.: Ensemble prediction of coastal flood risk arising from overtopping by linking meteorological, ocean, coastal and surf zone models, Q. J. Roy. Meteorol. Soc., 139, 298-313, 2013. 